\title{
STRATIGRAPHY AND CHRONOLOGY OF PLEISTOCENE COASTAL DEPOSITS IN NORTHERN AQUITAINE, FRANCE: A REINVESTIGATION.
}

\author{
Mathieu BOSQ ${ }^{1}$, Pascal BERTRAN ${ }^{1,2}$, Cédric BEAUVAL ${ }^{3}$, \\ Sebastian KREUTZER ${ }^{4}$, Mathieu DUVAL ${ }^{5}$, Melanie BARTZ ${ }^{6}$, \\ Norbert MERCIER ${ }^{4}$, Luca SITZIA7 ${ }^{7}$, Pierre STÉPHAN ${ }^{8}$
}

\begin{abstract}
Pleistocene deposits exposed along the coast of the Médoc area, south-west France, represent valuable palaeoenvironmental archives that have been the subject of extensive work in the past few decades. To further understand the palaeoenvironmental history and sedimentary dynamics of these deposits, a detailed lithostratigraphic study was performed on a series of new sections. Additionally, new chronological data were obtained from the combination of luminescence (OSL, IR-RF) and electron spin resonance (ESR) dating of quartz and feldspar grains (Kreutzer et al., 2018). The investigated sections comprise estuarine, lacustrine and peaty deposits (Négade Formation, Argiles du Gurp Formation), aeolian sands (Sables du Gurp Formation) and colluvial units (Grès de l'Amélie Formation). The Argiles du Gurp Formation, in which many remains of Palaeoloxodon antiquus were found, support the hypothesis of a progressive replacement of a tide-influenced marsh by a peaty fresh-water pond during the Holsteinian Interglacial (MIS 11). IR-RF dating of green estuarine clays at L'Amélie, in the northernmost part of the investigated area, strongly suggests that they do not belong to the Argile du Gurp Formation, but were deposited during the MIS 9 sea level highstand. The estuarine deposits are overlain by sandsheets (Sables du Gurp Formation) dated to MIS 10 and MIS 8 at Pointe de la Négade in the southern part of the study area, and to MIS 8 at L'Amélie. Syngenetic frost cracks testify to a periglacial depositional environment. Regional studies show that the Sables du Gurp Formation is a local equivalent of the Sables des Landes Formation, and corresponds to the oldest aeolian phase recorded in south-west France so far. Colluvial material (Grès de l'Amélie Formation) dated to the Weichselian pleniglacial (MIS 2) fill small palaeo-valleys incised in the Sables du Gurp Formation. Holocene coastal dunes cover the whole sequence.
\end{abstract}

Keywords: coversand, Argiles du Gurp, Palaeoloxodon antiquus, Aquitaine basin, Middle Pleistocene, OSL, IR-RF, ESR

\section{RÉSUMÉ}

RÉVISION STRATIGRAPHIQUE ET CHRONOLOGIQUE DE LA SÉQUENCE PLÉISTOCÈNE DU LITTORAL NORD-AQUITAIN. Une synthèse des travaux antérieurs associée à une analyse stratigraphique détaillée et des datations numériques (OSL, IR-RF, ESR) des affleurements pléistocènes du littoral de la péninsule médocaine permettent d'établir un nouveau cadre chronostratigraphique des dépôts. Nos résultats montrent la présence de niveaux estuariens, palustres et tourbeux (Formation de la Négade, Argiles du Gurp), d’épandages sableux éoliens (Formation des Sables du Gurp) et de colluvions (Formation des Grès de l'Amélie). La Formation des Argiles du Gurp, célèbre pour ses restes d'éléphants appartenant au taxon Palaeoloxodon antiquus, enregistre le passage progressif d'un environnement estuarien à un marais d'eau douce pendant l'Hostenien (SIM 11). Des dépôts tourbeux (lignite) terminent le comblement du marais à la fin de l'interglaciaire. La datation par IR-RF d'argiles vertes estuariennes à l'Amélie, dans la partie septentrionale de la zone étudiée, suggère que ces dépôts n'appartiennent pas à la Formation des Argiles du Gurp, mais se sont déposés pendant le haut niveau marin du SIM 9. L’emboitement de formations estuariennes de plus en plus récentes vers le nord indiquerait la migration progressive de la Garonne au cours du Pléistocène. Les niveaux estuariens et tourbeux sont recouverts par des épandages éoliens en nappe (Formation des Sables du Gurp) datées par IR-RF et ESR des SIM 8 et 10 dans la partie sud de la zone étudiée (Pointe de la Négade) et du SIM 8 à l’Amélie. La présence de fentes de gel syngénétiques témoigne d’un contexte périglaciaire lors du dépôt des sables. Les études régionales montrent que les Sables du Gurp, qui sont un équivalent latéral de la Formation des Sables des Landes, correspondraient à la plus ancienne phase éolienne enregistrée à ce jour dans le sudouest de la France. Les formations pléistocènes sont recouvertes par des dunes holocènes récentes.

Mots-clés : Sables des Landes, Argiles du Gurp, Palaeoloxodon antiquus, Bassin aquitain, Pléistocène moyen, OSL, IR-RF, ESR

\footnotetext{
${ }^{1}$ PACEA, UMR 5199, CNRS, Université de Bordeaux, bâtiment B2, allée Geoffroy-Saint-Hilaire, CS 50023, FR-33615 PESSAC cedex. Courriel : mathieu.bosq@gmail.com

${ }^{2}$ Inrap, 140 avenue du Maréchal Leclerc, FR-33130 BÈGLES.

${ }^{3}$ Archéosphère, 2 rue des Noyers, FR-11500 QUIRBAJOU.

${ }^{4}$ IRAMAT-CRP2A, UMR 5060, CNRS Université Bordeaux Montaigne, Maison de l’Archéologie, FR-33607 PESSAC cedex.

${ }^{5}$ Australian Research Centre for Human Evolution (ARCHE), Environmental Futures Research Institute (EFRI), AU-QLD-4111 NATHAN.

${ }^{6}$ Institute of Geography, University of Cologne, Albertus-Magnus-Platz, DE-50923 COLOGNE.

${ }^{7}$ Universidad de Tarapacá, Instituto de Alta Investigación, Laboratorio de Análisis e Investigaciones Arqueométricas, CL-15201010069 ARICA.

${ }^{8}$ CNRS, Université de Bretagne Occidentale, LETG, UMR 6554, CNRS, Institut Universitaire Européen de la Mer, rue Dumont d’Urville, FR-29280 PLOUZANÉ.
} 


\section{1 - INTRODUCTION}

Médoc is a $80 \mathrm{~km}$ long peninsula located in the north of the Aquitaine basin, bounded by the Atlantic Ocean to the west, the Gironde estuary to the east and the Arcachon-Bordeaux axis to the south (fig. 1). Along the Atlantic, the coast is bordered by a quasi-continuous Holocene dune field whose height can reach up to $40 \mathrm{~m}$. Pleistocene deposits have been identified since 1875 beneath the Holocene dunes following the discovery of a mandible of fossil elephant (Gassies, 1875; DulignonDesgranges, 1877). Since then, many studies have been dedicated to the description of the geological formations outcropping along the coast (Welsch, 1911; Fabre, 1936, 1939; Paquereau \& Schoeller, 1959; Elhaï \& Prenant, 1963; Dubreuilh, 1971; Dubreuilh et al., 1971; Dubreuilh \& Marionnaud, 1973; Diot, 1999; Tastet, 1999). These studies were the subject of a lithostratigraphic synthesis by Dubreuilh (1971), and more recently by Tastet (1999), but only few numerical ages were available at that time. New elephant remains were discovered in 1994 and 2000 in the "Argile du Gurp" Formation and attributed to the taxon Palaeoloxodon antiquus (Beauval et al., 1998; Michel, 2002). At the same time, the pollen analysis of the lower part of the sequence allowed reconstruction of the depositional environments (O’Brien \& Jones, 2003). However, the chronologies proposed following these studies remain contradictory.
As part of the LITAQ project led by F. Verdin and F. Eynaud, we carried out new field analyses and numerical dating of the Pleistocene lithostratigraphic units using Electron Spin Resonance (ESR) and luminescence dating (OSL, IR-RF) methods on quartz and feldspar grains (see Kreutzer et al., 2018 for further detail). The re-investigation of the sequence benefited from (1) the current erosion of the coastline, which exposes the Pleistocene and Holocene formations along a cliff, and (2) a previous chronostratigraphical reassessment of the aeolian "Sable des Landes" Formation which develops inland over wide areas (Bertran et al., 2009, 2011; Sitzia, 2014; Sitzia et al., 2015).

Our contribution aims at further constraining the palaeoenvironmental and chronological framework of the sedimentary sequence. Therefore, we (1) propose a synthesis of the geological data currently available for the northern Médoc coast, (2) establish a chronostratigraphic framework for the Pleistocene formations, and (3) replace the updated depositional sequence within the Quaternary history of the Aquitaine basin.

\section{2 - GEOGRAPHICAL AND GEOLOGICAL SETTING}

Since the Miocene, the Aquitaine basin has been filled by fluvial and deltaic deposits fed by the Massif Central

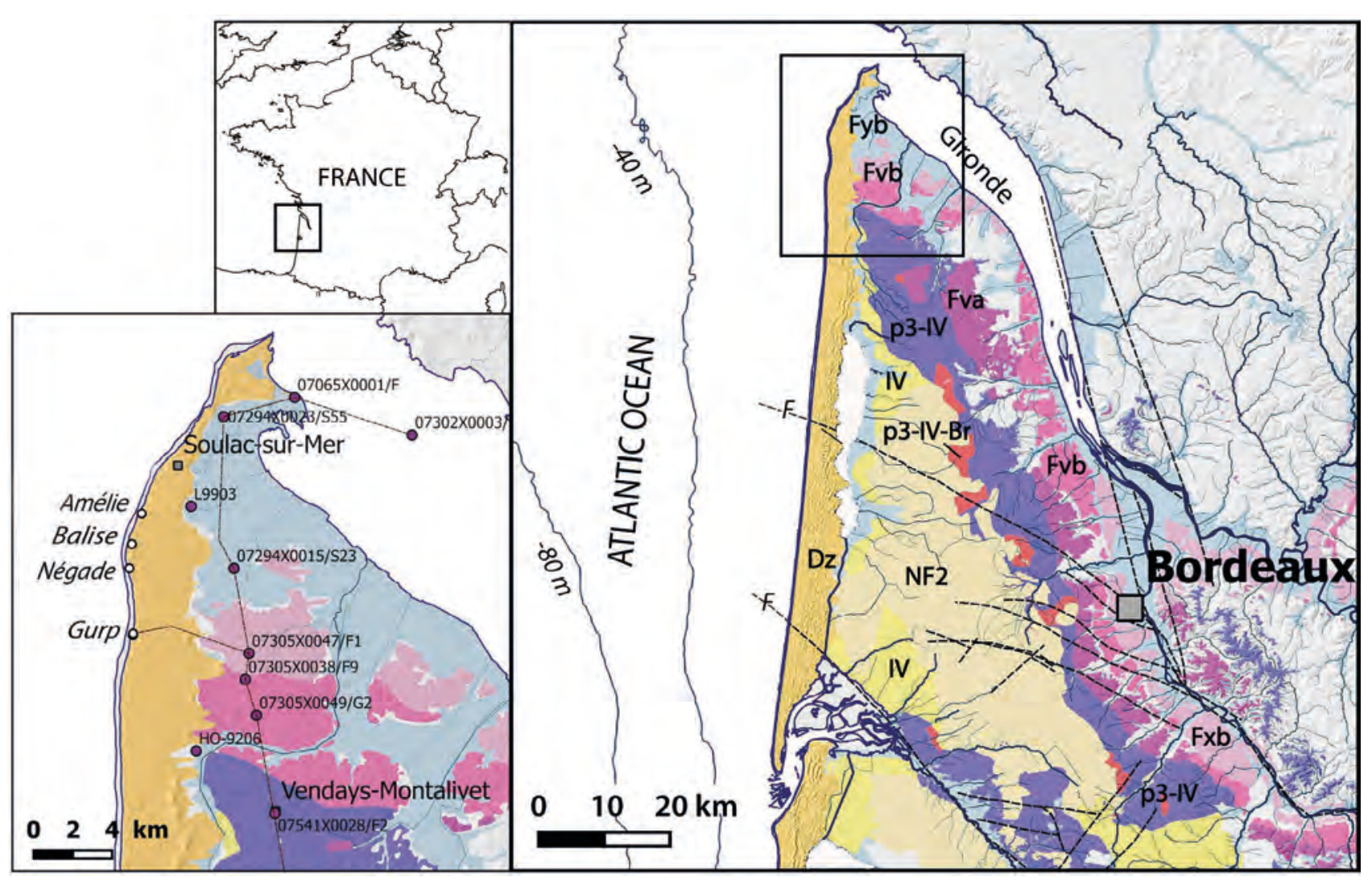

Fig. 1: Location of the study area and harmonised geological map of the Médoc area (scale 1:50,000; infoterre.brgm.fr).

Left: location of the boreholes used for the sections shown in figures 2 and 4. Dz - coastal dunes ; NF2, IV - Sables des Landes Formation (aeolian) ; p3-IV, p3-IV-Br - Belin Formation (plateau alluvium); Fva, Fvb, Fxb - Pleistocene alluvium ; Fyb - recent alluvium, coastal marshes.

Fig. 1 : Localisation de la zone étudiée et carte géologique harmonisée à $1 / 50000$ du Médoc (infoterre.brgm.fr). A gauche : localisation des sondages utilisés pour les coupes illustrées sur les figures 2 et 4. Dz - dunes côtières; NF2, IV - Formation du Sables des Landes ; p3-IV, p3-IV-Br - Formation de Belin (alluvions des plateaux) ; Fva, Fvb, Fxb-alluvions pléistocènes ; Fyb-alluvions récentes, marais côtiers. 
and the Pyrenees (Vigneaux, 1975; Dubreuilh et al., 1995). The continental deposits were studied in detail by Dubreuilh et al. (1995) who distinguished five sequences prograding towards the north, (1) the Sables Fauves Formation and Glaises Bigarrées Formation (sequence 1, Miocene), (2) the Arengosse Formation, Solferino and Mézos members (sequences 2 and 3, Pliocene), (3) the Onesse Formation (sequence 4, basal Lower Pleistocene), (4) the Belin Formation (sequence 5, Lower Pleistocene). A reconstruction of the palaeogeographical evolution of the basin fill from borehole sections (Dubreuilh et al., 1995; Karnay et al., 2010) shows a gradual northward migration of the depocentre, from sequence 1 to 5 . During the Lower Pleistocene, the geometry of the most recent sequence (Belin Formation) foreshadows the current Garonne valley. The Belin Formation extends over most of the Medoc peninsula with the exception of the northernmost part. Incision of the fluvial system began during the Lower Pleistocene. Valley deepening and terrace formation were accompanied by the migration of the palaeo-Garonne to the northeast. During the Middle and Upper Pleistocene, the Médoc area appeared as a "plateau" inclined towards the Atlantic Ocean, devoid of topographic obstacles and poorly drained. This topography enabled widespread deposition of aeolian coversands (Sables des Landes Formation sensu lato, Legigan, 1979; Sitzia et al., 2015). The main source for the sands was the continental shelf which emerged during glacial sea-level lowstands. During the Holocene, the aeolian accumulation was limited to coastal dunes, while mud and peat deposition took place simultaneously in estuarine marshes.

\section{3 - MATERIAL AND METHODS}

\section{1 - GEOLOGY}

The geographical area covered by this study extends along the coast between Soulac-sur-Mer to the north and the Anse du Gurp to the south. It has been divided into sub-zones (Clavé, 2001), which include, from south to north, Anse du Gurp, Pointe de la Négade, La Balise, L'Amélie. Behind the beach, the Holocene dunes and the underlying Pleistocene formations are eroded into a 4-5 m high cliff. The main observations and measurements were carried out during field campaigns in 2014 on four main profiles. The deposits located below the beach sands, however, were only observed in trenches. The altitude of some target spots was determined from topographic surveys carried out using a Terrestrial Laser Scanning (Riegl VZ400) at L'Amélie and Pointe de la Négade. The point clouds were georeferenced from reflective targets randomly positioned in the field and surveyed with DGPS (TopCon Hyper V) with an absolute precision of $\pm 5 \mathrm{~cm}$. All these data were recorded in the Lambert 93 projection system (EPSG-2154) and connected to the French (NGF) levelling system using a standard procedure of GPS data post-processing based on the permanent network of the Institut Géographique National (IGN).

Additional information was obtained from borehole data stored in the Banque du Sous-Sol (BSS) of the Bureau des Recherches Géologiques et Minières (BRGM) (http:// infoterre.brgm.fr/). The map of alluvial formations was extracted from the harmonised geological map of France (scale 1:50000; http://infoterre.brgm.fr/). The dataset was integrated using a Geographical Information System (ESRI ArcGIS). The Aster Digital Elevation Model (DEM) with a horizontal resolution of $30 \mathrm{~m}$ (http://gdem. ersdac.jspacesystems.or.jp/) was used. Bathymetry data were obtained from the European Marine Observation and Data Network (EMODnet) database available online (http://www.emodnet-hydrography.eu/). Finally, the IGN Cartage database (http://professionnels.ign.fr) was used for the hydrographic network.

Grain-size analysis was carried out in the PACEA laboratory (Université de Bordeaux) using a Horiba LA-950 laser particle size analyser. Sample pre-treatment included suspension in sodium hexametaphosphate (5 g/l) and hydrogen peroxide (35 \%) for $12 \mathrm{~h}$, and $60 \mathrm{~s}$ of ultrasonification in the analyser to achieve optimal dispersion. The Mie solution to Maxwell's equations provided the basis for calculating particle size as recommended by the ISO committee (Jones, 2003; ISO, 2009), using a refractive index of 1.333 for water and $1.55 \mathrm{i}-0.01 \mathrm{i}$ for the particles. Additionally, large thin sections were prepared from undisturbed blocks of sediment vacuum-impregnated with a polyester resin following the method described by Guilloré (1980).

\section{2 - CHRONOLOGY}

The chronological framework was established by combining luminescence and ESR dating methods. Six sediment samples were initially collected for luminescence dating purpose (BDX16646 to BDX16651) and were processed at the luminescence dating laboratory of the IRAMAT-CRP2A in Bordeaux, France. The samples were taken from previously prepared sections under daylight conditions using opaque steel cylinders. Sample preparation followed standard procedures (e.g. Preusser et al., 2008) for coarse-grained quartz and feldspar (100-200 $\mu \mathrm{m})$. Among the six samples, three (BDX16649, BDX16650 and BDX16651) were also used for ESR dating. The analyses were carried out at the Geochronology facilities of the Centro Nacional de Investigación sobre la Evolución Humana (CENIEH, Burgos).

Optically stimulated luminescence (OSL) ages for quartz grains from samples BDX16646 and BDX16651 were determined using an adapted single aliquot regenerative (SAR) dose protocol (Murray \& Wintle, 2000). Age estimates from potassium-rich coarse feldspar grains of samples BDX16647, BDX16648, BDX16649 and BDX16650 were obtained from modified infrared radiofluorescence (IR-RF; Trautmann et al., 1999; Erfurt \& Krbetschek, 2003) SAR protocol following the procedure described by Frouin et al. (2017). The ESR 
dating followed the multiple centres (MC) approach (Toyoda et al., 2000) and the standard multi-grain Multiple Aliquots Additive Dose (MAAD) method as described in Duval et al. (2017). Following the recent conclusion by these authors, only the ESR age results based on the Ti-H signals are presented in this study. A detailed comparison of the results derived from each centre may be found in Kreutzer et al. (2018).

For dose rate determination, gamma-dose rate was measured in situ using a portable gamma-ray spectrometer (Inspector 1000, LaBr probe; procedure: Mercier \& Falguères, 2007; Guérin \& Mercier, 2011). U, Th and $\mathrm{K}$ concentrations were obtained by high-resolution gamma-ray spectrometry analyses of raw sediment at the IRAMAT-CRP2A. DRAC software (v1.2; Durcan et al., 2015) was used for age and dose rate calculations (see Kreutzer et al., 2018 for further details). The gamma-ray spectrometry results were analysed using self-written (unpublished) MS Excel ${ }^{T M}$ spreadsheets. Luminescence data were analysed using the R package 'Luminescence' (v0.7.4; Kreutzer et al., 2012, 2017).

\section{4 - RESULTS}

\section{1 - GENERAL PATTERN OF THE QUATERNARY FORMATIONS IN THE NORTHERN MÉDOC AREA, DATA FROM THE LITERATURE}

At the scale of Médoc as a whole, the main lithostratigraphic units distinguished by the authors include, from the oldest to the most recent (fig. 1):

(1) At the base, the Tertiary marine substratum is mainly composed of Upper Eocene to Oligocene limestones (Dubreuilh \& Marionnaud, 1973; Vigneaux, 1975), which dip a few degrees towards the ocean. Eocene limestones are visible below water a few hundred metres off Pointe de la Négade between -6 m and -22 m (Froidefond et al., 1984). The limestone is strongly karstified (Courrèges, 1997).

(2) Fluvial and fluvio-deltaic deposits (Dubreuilh et al., 1995; Karnay et al., 2010) with thicknesses ranging from $5 \mathrm{~m}$ to $30 \mathrm{~m}$. They comprise silty clay, interpreted as belonging to the upper Onesse Formation (basal Lower Pleistocene), then sand with small whitish gravel typical of the Belin Formation (Lower Pleistocene). This unit, denoted p3-IV on the harmonised geological map, crops out in the southern area and forms the frame of the Médoc plateau.

(3) Gravelly terraces bordering the Garonne plain. The 1:50000 geological map reveals four levels above the estuarine marshes, noted Fva (the highest), Fvb, Fxa and Fxb (the lowest). This terrace staircase marks successive stages of river downcutting since the Lower Pleistocene (fig. 2). No numerical dating is available so far to estimate the age of the alluvial deposits. Detailed mapping in the Margaux-Arsac area by Tastet and Becheler (2012) showed, however, that the number of terraces is probably higher than that shown on the 1:50000 geological map. These authors identified six levels (T1 to T6 from the oldest to the youngest) below the plateau alluvium (Belin Formation).

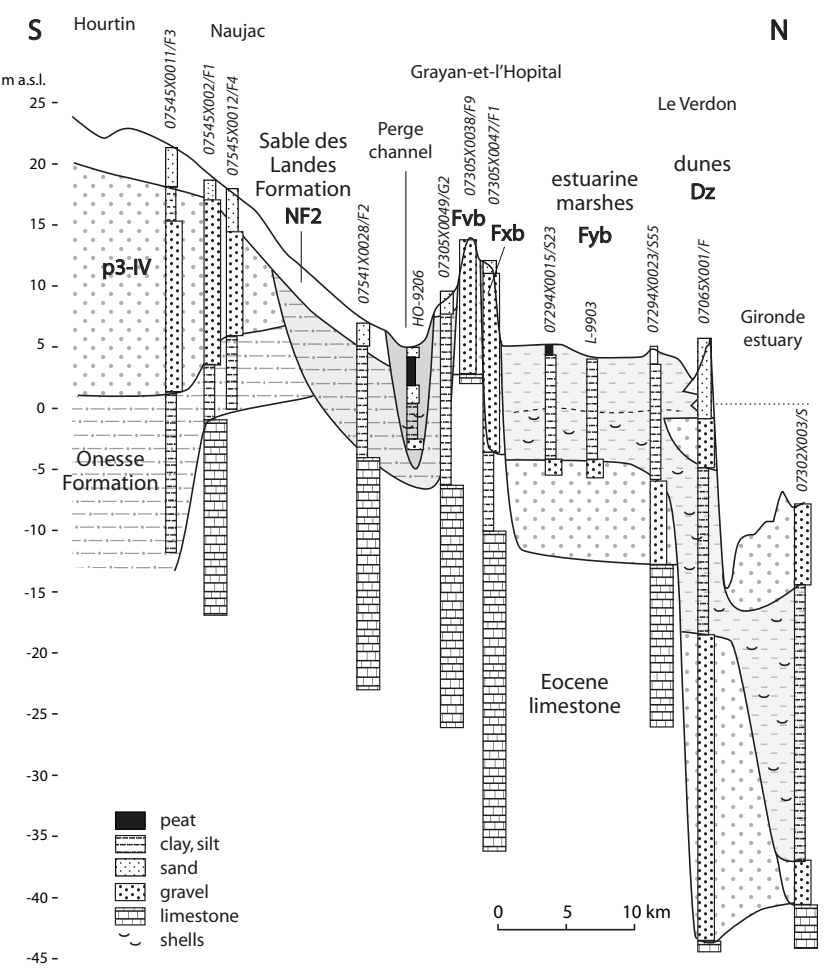

Fig. 2: Schematic sketch of the Médoc section from the south to the north.

The location of the boreholes is indicated in figure 1 .

Fig. 2 : Coupe schématique sud-nord du Médoc. La position des sondages est indiquée sur la figure 1.

(4) Aeolian sands (Sables des Landes, noted NF2 on the geological map) covering almost all of the alluvial formations. Their thickness locally exceeds $10 \mathrm{~m}$ and decreases towards the east, to give way to ventifact lags on the higher terraces. According to Sitzia et al. (2015), the coversands are mainly fed by deflation of the continental shelf during cold phases of the Middle and Upper Pleistocene. Infrared Stimulated Luminescence dating of feldspars (IRSL) at Jolles near Hourtin provided a minimum age of $231 \pm 19 \mathrm{ka}$ (Sitzia et al., 2015). The Hourtin sequence thus shows that sand drifting was active inland in Médoc at least as early as MIS 8. Older ages, contemporaneous with MIS 10, were also obtained further south on coversands near Bordeaux (Sitzia et al., 2015).

(5) Holocene coastal dunes, noted Dz on the geological map, 5 to $9 \mathrm{~km}$ in width. The ${ }^{14} \mathrm{C}$ dates obtained on palaeosols within the sands (Tastet, 1998; Tastet \& Pontee, 1998; Clavé, 2001) and the IRSL dates on sand layers (Clarke et al., 1999, 2002; Clavé, 2001) show that dune emplacement started at $3.6 \mathrm{ka}$ for the Dune du Pilat near Arcachon south of the study area, and later in Médoc to the north $(1.3 \mathrm{ka})$. Two generations of coastal dunes are currently visible in the landscape. The oldest consisting of overlapping parabolic dunes ("primary dunes") has delivered ${ }^{14} \mathrm{C}$ ages between $1.3 \mathrm{ka}$ and $0.9 \mathrm{ka}$, while the youngest ("modern dunes") dates to the Little Ice Age (0.5 to $0.25 \mathrm{ka}$ ). The modern dunes include parabolic dunes, barchans and coalescent barchans.

(6) Holocene marsh sediments along the estuary. Recent palaeoenvironmental studies (Diot \& Tastet, 1995; Ponte et al., 1998; Clavé, 2001; Coquillas et al., 2006) have mapped the marshes and their Holocene evolution. 


\section{2 - MAIN LITHOSTRATIGRAPHIC UNITS VISIBLE ALONG THE COAST}

In his synthesis, Tastet (1999) distinguished five main lithostratigraphic units outcropping along the coast. Our field survey led to similar observations, except for unit 1. Consequently, apart from one case, the name of these units was kept throughout the manuscript. Four typesections illustrate the diversity of the lithofacies and the lateral changes (fig. 3).

\subsection{1 - Unit 1: Négade Formation}

As indicated by Dubreuilh (1971), the Négade Formation is only sporadically visible on the foreshore during exceptional episodes (highest tides, storms) and in a limited geographical area (Pointe de la Négade). According to Dubreuilh (1971) and Tastet (1999), the unit consists of laminated clay with mollusc shells, overlain by clayey sand and gravel with planar cross bedding (hydraulic dunes). The total thickness of the unit is approximately $1.0 \mathrm{~m}$ (Dubreuilh, 1971). The stratigraphical relationship with the mapped alluvial terraces in the area remains difficult to determine. The section proposed in figure 4 , based on the borehole data from the BRGM database, suggests that the Négade Formation is likely to be a lateral equivalent of (or lies unconformably over) the Fxb alluvial terrace. Multi-proxy analysis (pollen, plant macrofossils,

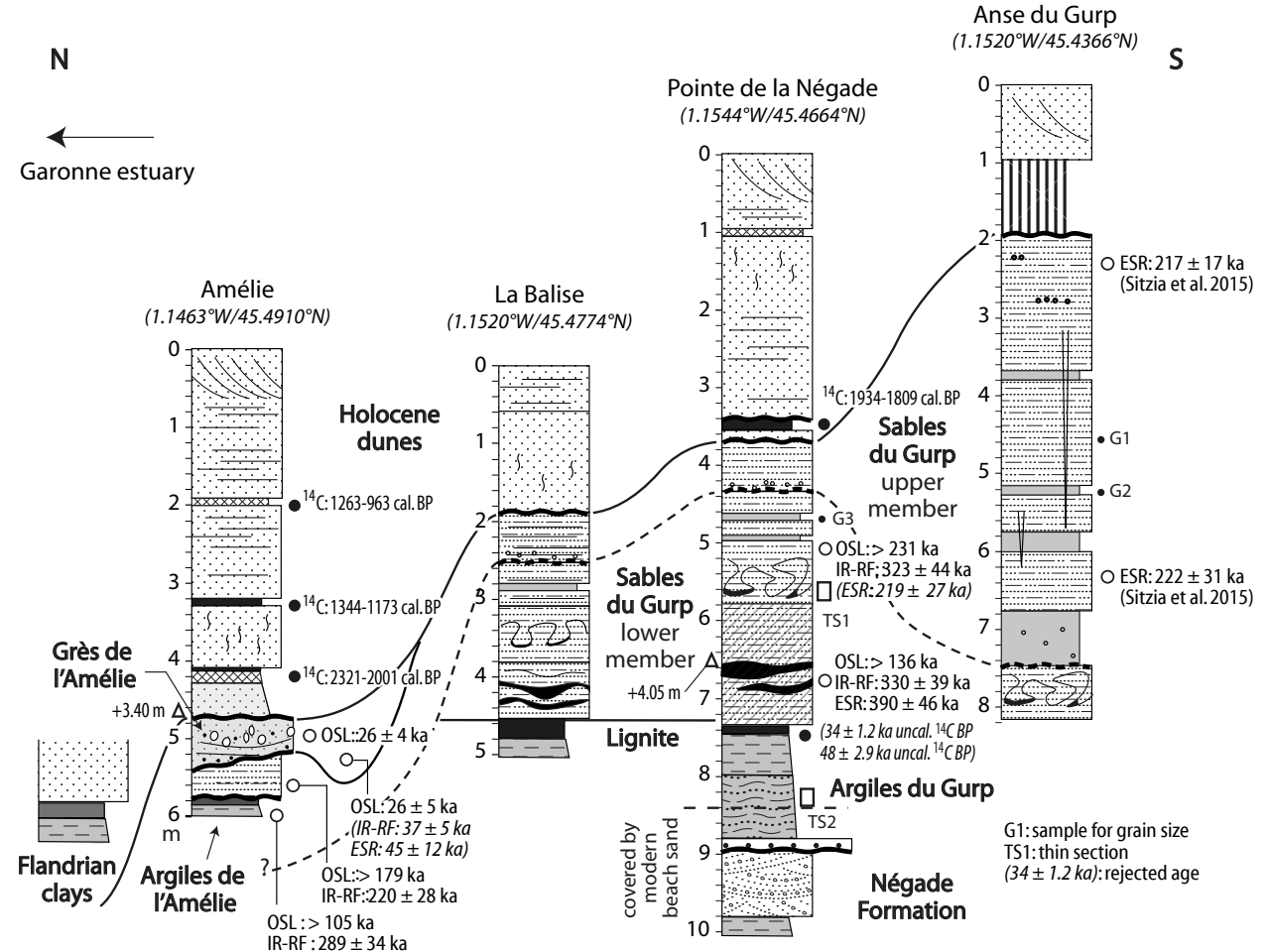

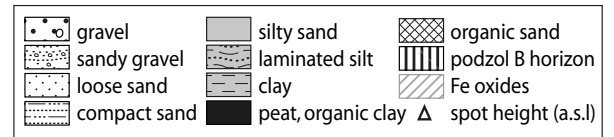

Fig. 3: Generalised stratigraphy of the four investigated sections including the sampling location for radiocarbon (from Eynaud $e t$ al., 2016), luminescence and ESR dating (Kreutzer et al., 2018).

All sections are exposed along the coastal cliff. When calibrated, the radiocarbon ages are given with a $2 \sigma$ uncertainty (Calib 7.0.4, IntCal13). ESR age estimates derived from Sitzia et al. (2015) are based on the Al centre, while those from the present work were obtained from the measurement of the $\mathrm{Ti}-\mathrm{H}$ centre. The geographic coordinates are in WGS84.

Fig. 3 : Stratigraphie générale des coupes étudiées et localisation des échantillons datés par radiocarbone (d'après Eynaud et al., 2016) et par Luminescence et ESR (Kreutzer et al., 2018). Toutes les coupes sont exposées le long de la falaise côtière. Les âges ${ }^{14} \mathrm{C}$ notés cal $\mathrm{BP}$ ont été calibrés à l'aide du logiciel Calib 7.0.4 en utilisant la courbe IntCal13 ; l'incertitude est indiquée à $2 \sigma$. Les âges ESR fournis par Sitzia et al. (2015) sont basés sur le centre Al, tandis que ceux mesurés dans le cadre de cette étude ont été obtenus à partir du centre Ti-H. Les coordonnées géographiques sont indiquées en WGS84.

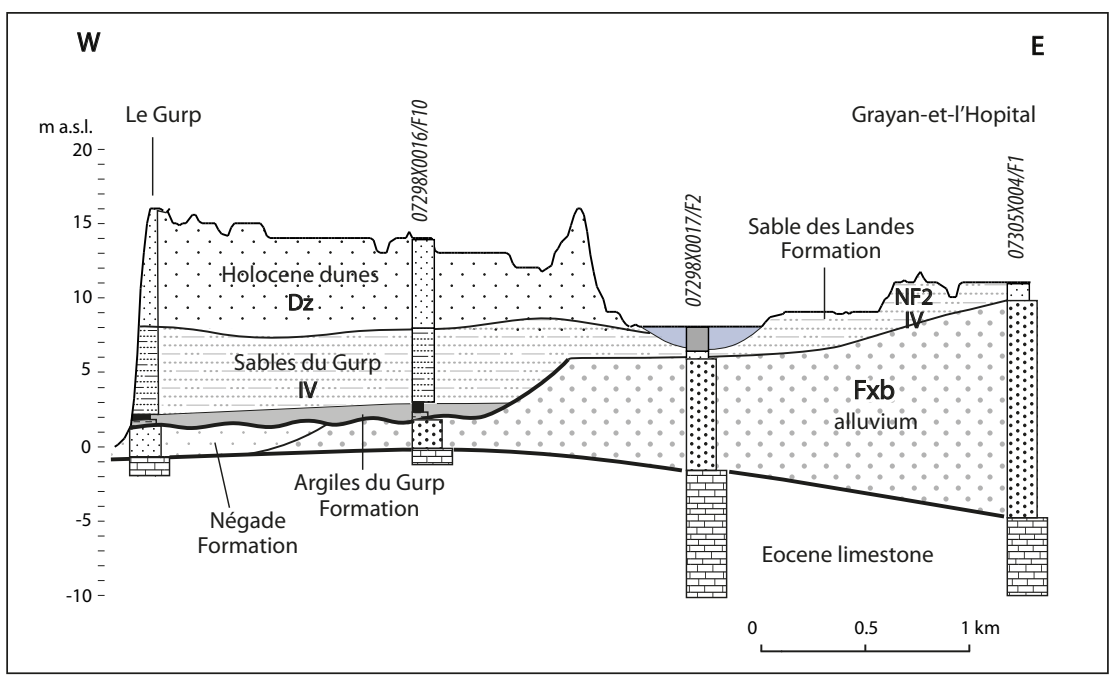

Fig. 4: Schematic section perpendicular to the coastline in the Anse du Gurp area.

The location of the boreholes is indicated in figure 1.

Fig. 4 : Coupe schématique perpendiculaire à la côte dans la zone d'Anse du Gurp. La localisation des sondages est indiquée sur la figure 1. 
dinoflagellates, beetles) has been carried out by O'Brien and Jones (2003). According to these authors, the pollen assemblages are typical of a brackish marsh with episodic freshwater inputs, and correspond to an interglacial. The taxa Tsuga and Pterocarya suggest this interglacial to be either the Tiglien (MIS 79-63) or the Waalien (MIS 49-37), or else the Bavelian (MIS 31-22). Only part of the interglacial has been recorded in the deposits.

\subsection{2 - Unit 2a: Argiles du Gurp}

This formation, which is visible in the lower part of the cliff, comprises at the base a level of polygenic pebbles lying unconformably on the Négade Formation ("Poudingue", not visible in the outcrop), followed by laminated grey sandy silts (ca. $1.0 \mathrm{~m}$ ) and massive green clays with slickensides $(0.2 \mathrm{~m}$ to $0.8 \mathrm{~m}$ ) (figs. 5 \& 6A). The basal unit (pebble level) covers a major unconformity between the Négade Formation and the overlying Argiles du Gurp, which is interpreted as a surface of marine abrasion. Unlike Tastet (1999), who included the pebble level within the Négade Formation, we consider it to be part of the Argiles du Gurp. The laminated sandy silts are interpreted as flaser bedded tidal deposits (Reineck \& Singh, 1980). According to
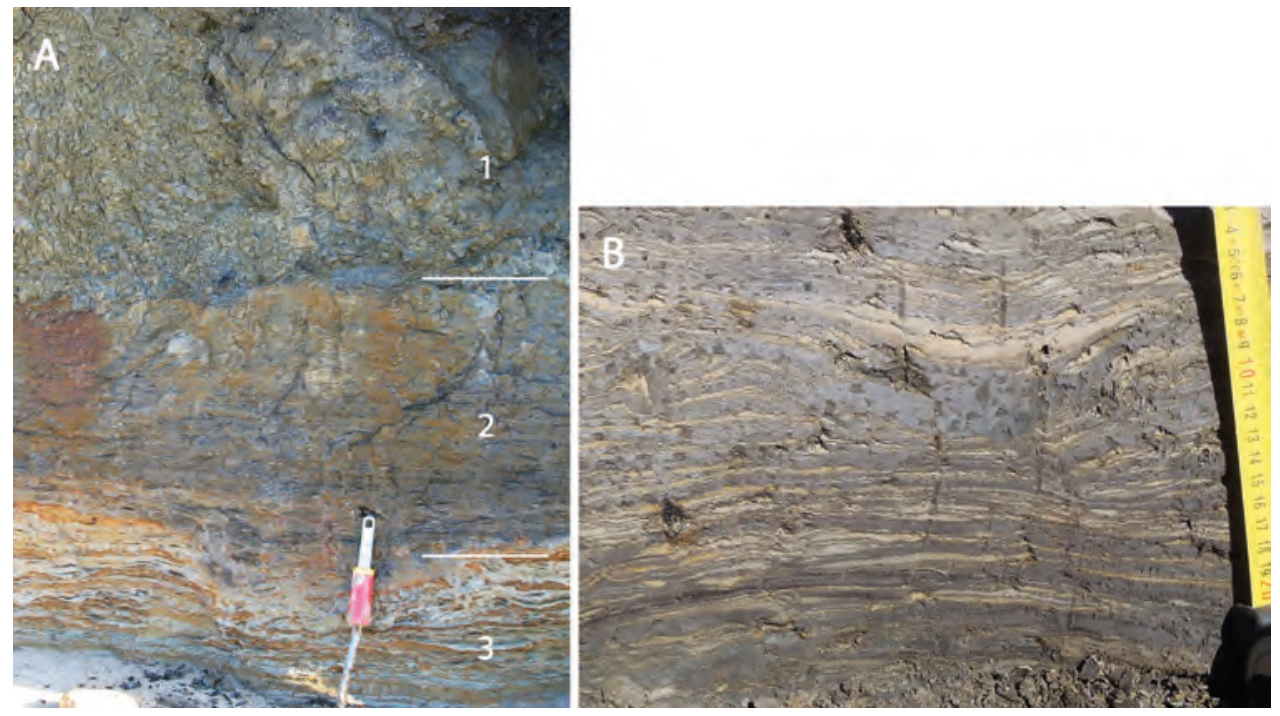

Fig. 5: A - Typical lithofacies of the Argiles du Gurp Formation at Pointe de la Négade; (1) massive green clay with slickensides, (2) flaser bedded clayey silts, (3) laminated fine sand and silt. B - Close-up of the flaser bedding.

Fig. 5 : A - Lithofaciès typique de la Formation des Argiles du Gurp à la Pointe de la Négade. (1) argiles vertes massives à slickensides, (2) silts argileux à litage en flaser, (3) sables fins et silts. $B$-Vue détaillée $d u$ litage en flaser.

Fig. 6: A - Thin section of bedded tidal silts (Argiles du Gurp), Pointe de la Négade; B - Thin section of silty sand showing a welldeveloped platy structure (Sables du Gurp), Pointe de la Négade; C - Close-up of the platy structure.

Fig. $6:$ A - Vue en lame mince des silts tidaux lités (Argiles du Gurp), Pointe de la Négade: $B$ - Vue en lame mince de sables silteux à structure lamellaire bien développée (Sables du Gurp), Pointe de la Négade ; C - Vue détaillée de la structure lamellaire.

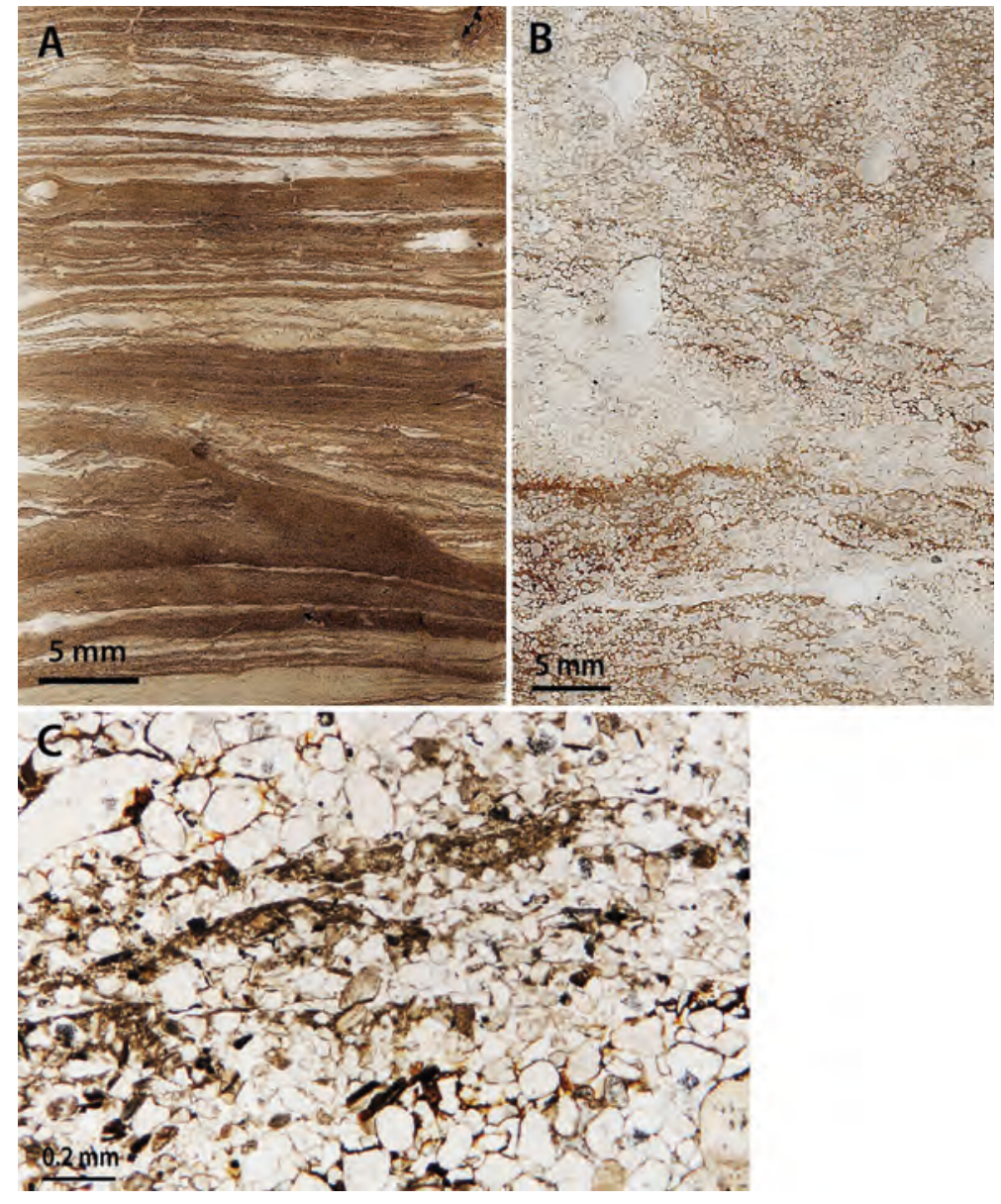


O’Brien and Jones (2003), the pollen assemblages yielded by samples taken at La Balise, Pointe de la Négade and Anse du Gurp evoke a brackish pond or an estuarine channel. The presence of aquatic plants such as Azolla filiculoides and Najas minor indicate deposition in a low-energy environment with episodic freshwater inputs (Haslam et al., 1982). The site was bordered by abundant vegetation and alder swamps, while the regional forest was dominated by oak (Quercus) and fir (Abies).

The overlying massive greenish clays correspond to pond deposits. At Pointe de la Négade, the top of these clays reaches ca. $+3.4 \mathrm{~m}$ a.s.l. According to the pollen assemblages, the marine influence decreases from the bottom to the top of the unit, which records the passage from a tide-dominated environment to a freshwater pond with abundant Azolla filiculoides (O’Brien \& Jones, 2003). This change is also accompanied by a change in the regional vegetation, which is dominated by pines at the expense of oaks and firs. According to the authors, this indicates disconnection of the water body with the sea, either linked to the natural evolution of the system or to sea-level lowering. Alder swamps occupy a prominent place while an increase in grass reflects the development of meadows near the freshwater pond.

On the section illustrated in figure 4, the Argiles du Gurp and the overlying sand units overlay unconformably the Fxb terrace and the Négade Formation, and fossilise an old cliff cut into the alluvium.

\subsection{3 - Unit 2b: Lignite}

The "Lignite", i.e. the upper member of the Argiles du Gurp Formation, corresponds to organic clay or fibrous, sometimes sandy peat with plant debris and tree trunks (fig. 7). The unit overlies the clay and reaches $0.1 \mathrm{~m}$ to $0.4 \mathrm{~m}$ in thickness. According to O'Brien and Jones (2003), the freshwater pond was progressively colonised by a reed bed dominated by sedges. The regional arboreal vegetation was almost exclusively composed of pines and points to the end of an interglacial, which can be assimilated to the Holsteinian (MIS 11) or possibly to the Landos (MIS 9) or that of Bouchet 1 (MIS 7).

\subsection{4 - Unit 3: Sables du Gurp}

The deposits, which are $3 \mathrm{~m}$ thick at La Balise and about $5 \mathrm{~m}$ thick in the Anse du Gurp area, comprise the following lithofacies:

(1) Grey to pale yellow medium sands (mode ranging from $300 \mu \mathrm{m}$ to $415 \mu \mathrm{m}$ ) with subhorizontal bedding (fig. 8). The sands are interstratified with bluish grey sandy silt beds a few centimetres thick and decreasing in frequency towards the top of the sections. Small ventifacts are present locally. The silty beds sometimes show involutions underlined by iron oxides. Under the microscope, a well-developed platy structure due to the formation of segregation ice is visible (fig. 6B, C). The sand beds are massive or have subhorizontal, often wavy or crinkly lamination, and show frequent inverse grading. The $20 \mathrm{~cm}$ to $60 \mathrm{~cm}$ thick transition with the underlying peat is progressive and composed of sand beds interlayered with organic clayey beds. This level is strongly involuted (Bertran et al., 2017) (fig. 9A). In some sections, the lower part of the sand below the involutions is indurated and coloured brown by illuviated organic matter. The indurated levels were named "Sables aliotisés” by Tastet (1999).

(2) Clayey sands with small gravels scattered or arranged in lenses. This lithofacies forms decimetre-thick layers which are rare at the Anse du Gurp but become more abundant at La Balise to the north.

A major unconformity cuts the Sables du Gurp Formation into two distinct members. At Pointe de la Négade, the unconformity corresponds to an erosional surface cutting the lower member at low angle and covered by a gravel lag. The lower member is composed of massive brown sand, involuted sand and clayey organic beds, followed by subhorizontally bedded sand. To the south at Anse du Gurp, the erosional surface is covered by a layer of grey sandy clay about $40 \mathrm{~cm}$ thick, followed by a thick sequence
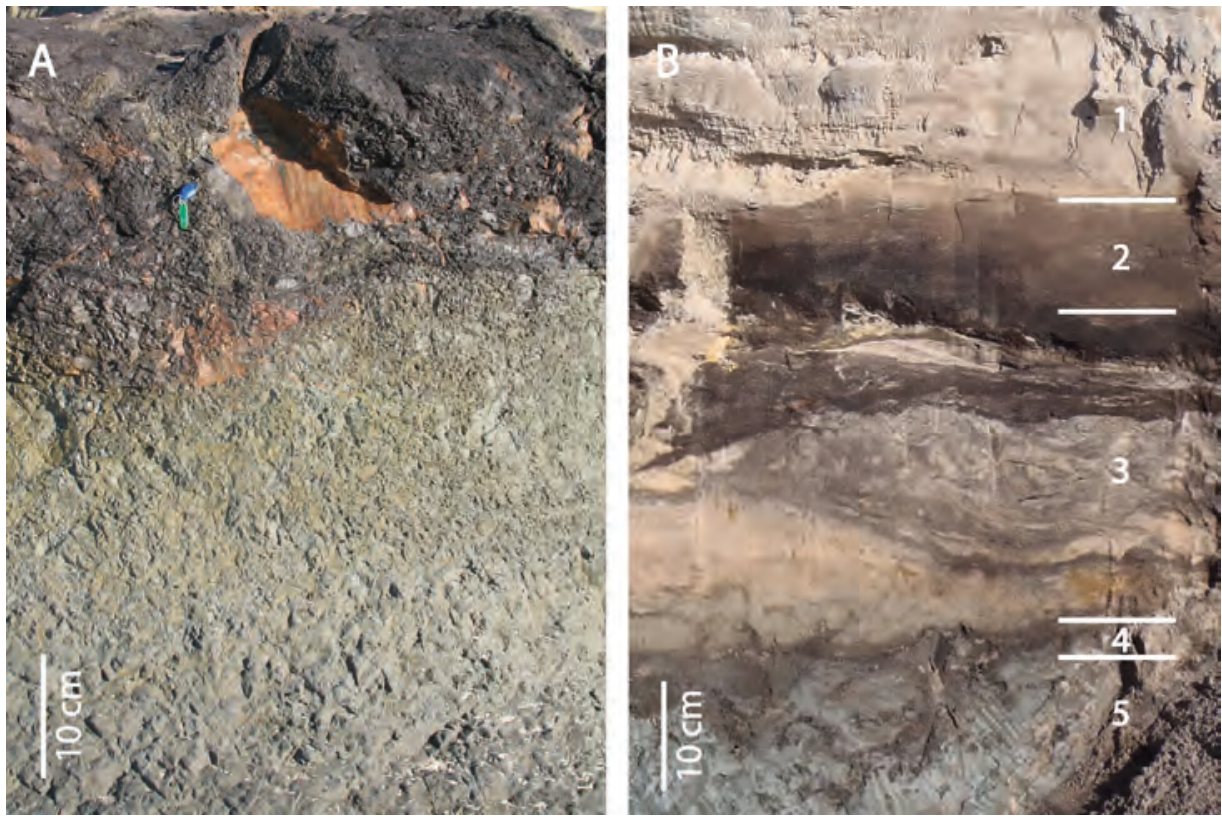

Fig. 7: A - Clayey peat with vegetal debris (Lignite) overlaying green clay, Pointe de la Négade; B - Transitional sequence between the Argiles du Gurp and the Sables du Gurp;

1 - horizontally bedded sand, 2 - sand slightly indurated by oxides ("Sables aliotisés"), 3 - alternating pale brown sand and black organic sand deformed by cryoturbation, 4 - organic clay (Lignite), 5 - green clay (Argiles du Gurp).

Fig. 7 : A - Tourbe argileuse à débris végétaux (Lignite) recouvrant les argiles vertes, Pointe de la Négade; $B$ - Séquence montrant le passage entre les Argiles du Gurp et les Sables du Gurp ; 1 - sable à litage horizontal, 2 - sable légèrement induré par des oxydes ("Sables aliotisés »), 3 - sable brun clair et sable noir organique déformés par cryoturbation, 4 - argile organique (Lignite), 5 - argile verte (Argiles du Gurp). 
Fig. 8: Lithofacies of the Sables du Gurp.

A - Horizontally bedded sand, Pointe de la Négade; a level of bluish grey sandy silt with scattered gravel is visible in the lower part of the photo; B - Sand and silty sand with wavy bedding and a small frost crack, Anse du Gurp; C - inverse grading (indicated by white arrows), Anse du Gurp; D - Sables du Gurp (2) eroded by lenticular gravel levels (1) ("Grès de l'Amélie”), L'Amélie.

Fig. 8 : Lithofaciès des Sables du Gurp. A - Sable à litage horizontal, Pointe de la Négade; un niveau de sable silteux gris bleu avec des graviers dispersés est visible dans la partie inférieure de la photo : B - Sable et sable silteux à litage ondulé et petites fentes de gel, Anse du Gurp ; C-Granoclassements inverses (indiqué par des flèches blanches), Anse du Gurp ; D - Sables du Gurp (2) érodés par des lentilles de sables et graviers (1) («Grès de l'Amélie »), L'Amélie.
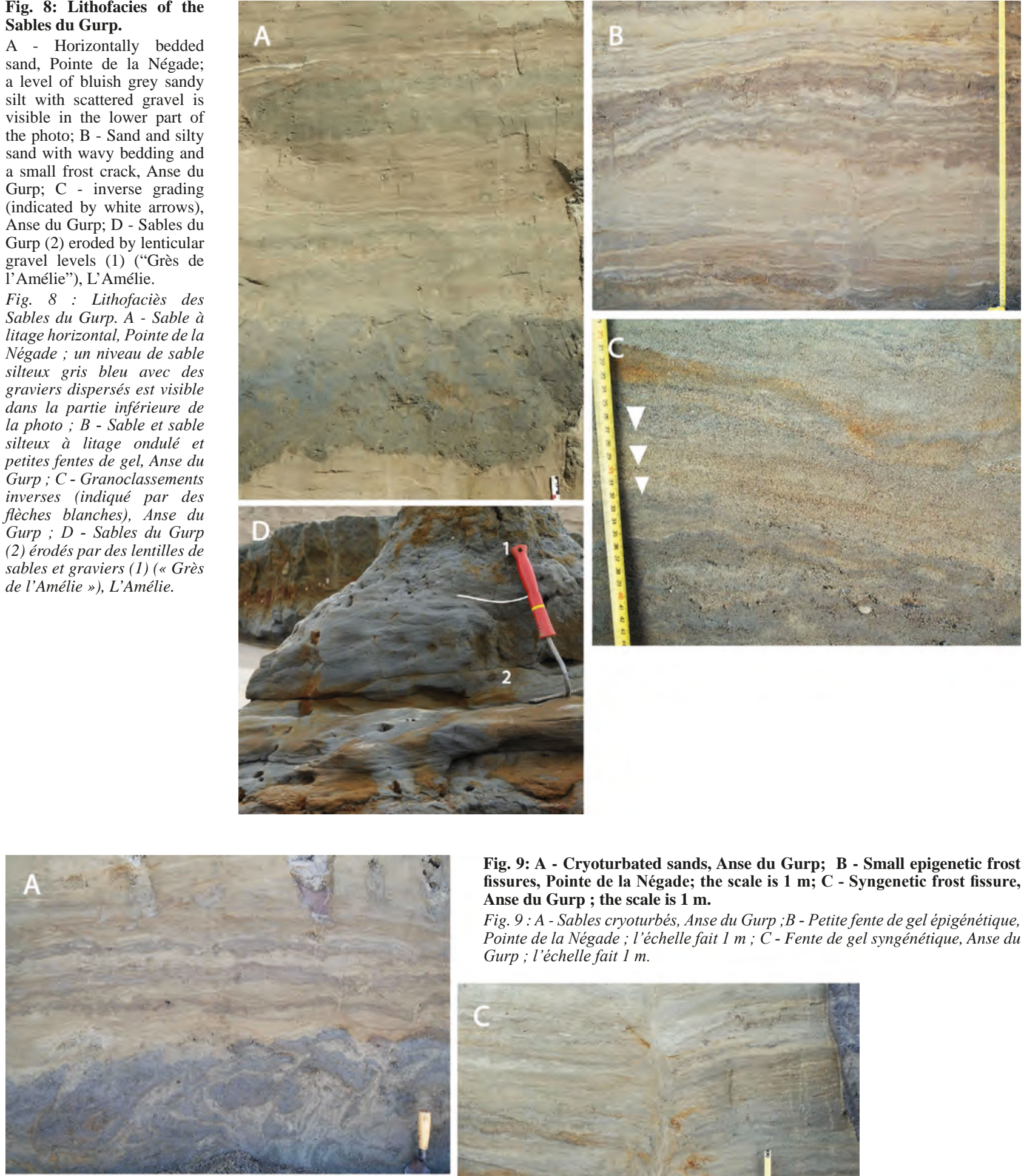

Fig. 9: A - Cryoturbated sands, Anse du Gurp; B - Small epigenetic frost fissures, Pointe de la Négade; the scale is $1 \mathrm{~m}$; C - Syngenetic frost fissure, Anse du Gurp ; the scale is $\mathbf{1} \mathbf{~ m}$.

Fig. 9 : A - Sables cryoturbés, Anse du Gurp ;B - Petite fente de gel épigénétique, Pointe de la Négade ; l'échelle fait $1 \mathrm{~m} ; C$ - Fente de gel syngénétique, Anse du Gurp ; l'échelle fait $1 \mathrm{~m}$.
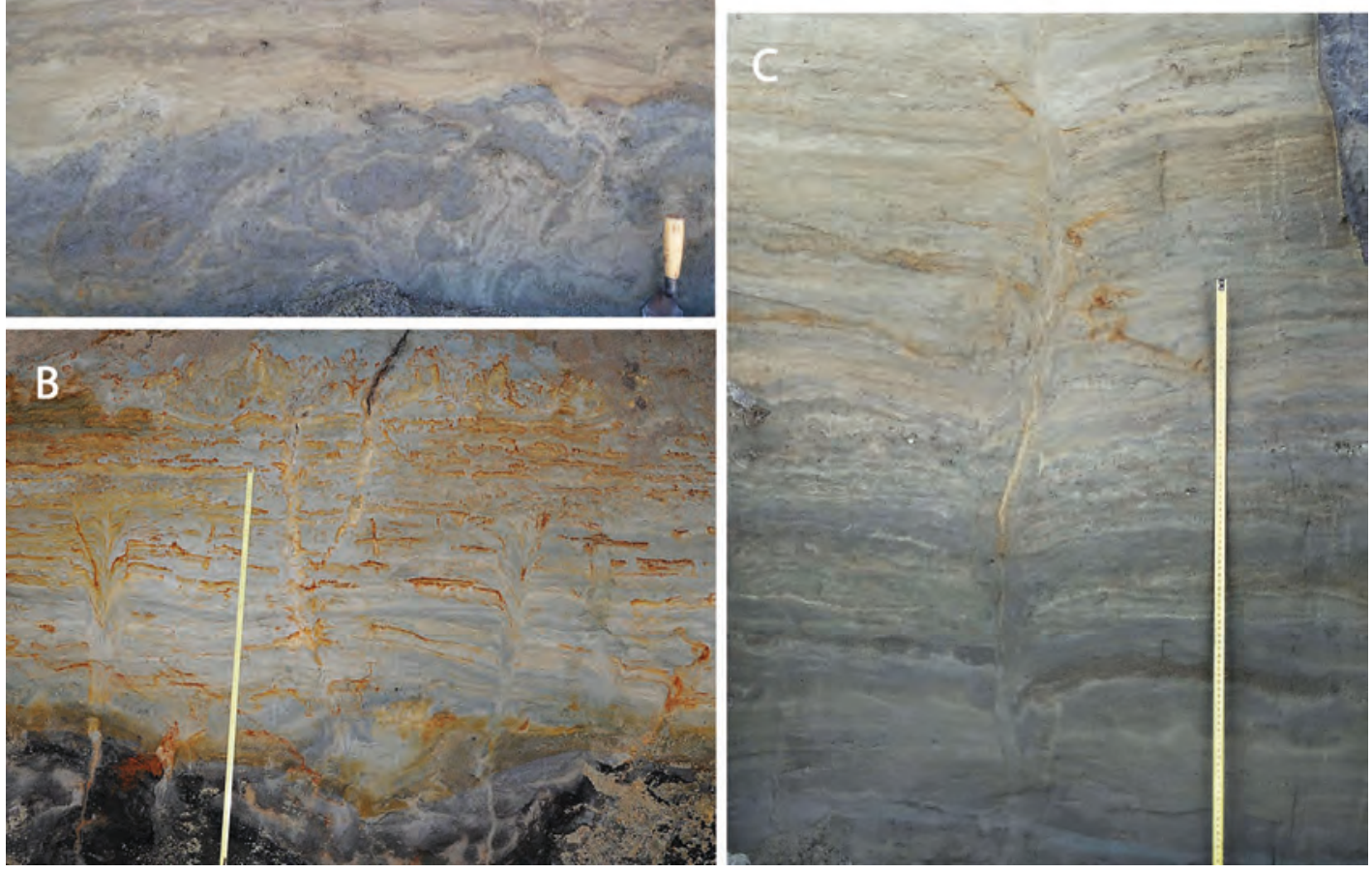
of subhorizontally bedded sand. At L'Amélie, on the other hand, the upper member rests directly on the basal clay. The unconformity thus reflects an undulating palaeotopography which is similar to that which shapes the upper member.

Many fissures are visible in the sand. They form either (1) structures a few centimetres wide and $0.5 \mathrm{~m}$ to $0.7 \mathrm{~m}$ high, with spacing that indicates that they form polygons of approximately $1 \mathrm{~m}$ diameter (fig. 9B), (2) structures up to $3 \mathrm{~m}$ high, a few centimetres wide and forming a series of encased funnels in the upper member of the Sables du Gurp (fig. 9C) or (3) sand wedges $15 \mathrm{~cm}$ wide and $1.5 \mathrm{~m}$ high, with their opening at the top of the Sables du Gurp Formation. The first two types of structures are interpreted as (cryo-)desiccation or thermal contraction cracks in the context of deep seasonal frost (Friedman et al., 1971; Romanovskij, 1973; Murton, 2013), either epigenetic or syngenetic, i.e. they resulted from repeated cracking of the ground during sedimentation. The sand wedges are epigenetic figures related to thermal contraction of the ground, possibly in a deep seasonal frost or permafrost context (Andrieux et al., 2016).

The Sables du Gurp Formation was observed from Anse du Gurp to L'Amélie to the north. According to Dubreuilh (1971), Dubreuilh and Marionnaud (1973) and Tastet (1999), the sands would have had a fluvial origin and were called "Formation des Sables Fluviatiles". For Sitzia (2014) and Sitzia et al. (2015), these deposits would be dominantly of aeolian origin. They were initially named “Sables de l’Amélie”. However, since the deposits are more visible in the Anse du Gurp sector, we propose here to rename them "Sables du Gurp". The deformation observed in the lower part of this formation can be easily followed along the coast and constitutes a benchmark horizon (fig. 8C). The involutions were identified by Dubreuilh (1971) and Tastet (1999) who attributed them to cryoturbation. New observations at Anse du Gurp (Sitzia, 2014), Pointe de la Négade and La Balise have provided some additional information. The thickness of the deformed zone is approximately $60 \mathrm{~cm}$. The morphology of the involutions varies considerably according to the section, and comprises sand diapirs, flames and large folds. According to Sitzia (2014), such deformation may reflect co-seismic liquefaction of the sands. However, the abundant traces of segregation ice lenses (platy structure) in fine-grained layers and the sand wedges strongly suggest that periglacial processes were most probably the triggering factors of deformation (periglacial load casting, Vandenberghe, 2013) (Bertran et al., 2017).

\subsection{5 - Unit 4: Grès de l’Amélie}

This unit, which reaches $1 \mathrm{~m}$ to $1.2 \mathrm{~m}$ in thickness, is exposed at the bottom of gullies or small valleys incised in the Sables du Gurp in the northern part of the study area. The lithofacies mainly consists of compact bluish grey clayey sands with scattered gravels and lenticular bedding (fig. 10). Better sorted and laminated sand beds are also intercalated within the coarser-grained lenses. These levels are locally deformed by involutions of

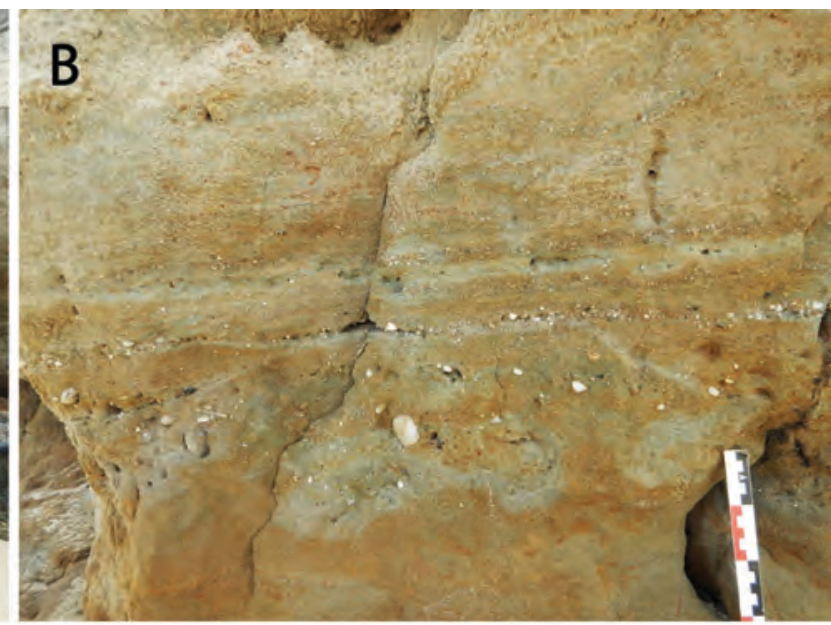

Fig. 10: Grès de l'Amélie.

A - Outcrop of the Grès de l'Amélie, L'Amélie; 1 - Grès de l'Amélie, 2 - organic clay, 3 - green clay; the scale is $0.5 \mathrm{~m}$; B - Close up view of the Grès de l'Amélie; the scale is $0.3 \mathrm{~m}$; C - View of the section sampled for luminescence and ESR dating; 1 - massive sand with gravel (Grès de l’Amélie), 2 - well-sorted sand (Sables du Gurp); the scale is $1 \mathrm{~m}$.

Fig. 10 : A - Affleurement des Grès de l'Amélie, L'Amélie : 1-Grès de l'Amélie, 2 - Argiles organiques, 3 -Argiles vertes ; l'échelle fait $0,5 \mathrm{~m} ; \mathrm{B}$-Vue détaillée des Grès de l'Amélie ; l'échelle fait $0,3 \mathrm{~m}$; $C$-Vue de la coupe échantillonnée pour datation par luminescence et ESR ; 1 - Sable massif à graviers (Grès de l'Amélie), 2 - Sable bien trié (Sables du Gurp); l'échelle fait $1 \mathrm{~m}$. 
smaller amplitude than those described in the Sables du Gurp Formation. The upper and lower limits correspond to erosional surfaces.

\subsection{6 - Unit 5: Holocene dunes}

Holocene dunes cover all the local Pleistocence deposits. Two major types of lithofacies were observed: (1) pale grey sand of $0.5 \mathrm{~m}$ to $2.0 \mathrm{~m}$ in thickness at the base, which are mainly massive due to bioturbation, with hydromorphic palaeosols (peaty gleys, histosols) or humic horizons (arenosols) interstratified within the sands (fig. 11A); (2) cross-bedded pale-yellow sands, typical of dunes with a well-developed avalanche face and with poorly developed soil horizons (arenosols) (fig. 11B).

\section{3 - ELEPHANT REMAINS}

Different remains of proboscidians have been discovered since 1875 along the Médoc coast. The first discovery consisted in a mandible of elephant thought to belong to the Lower Pleistocene species Mammuthus meridionalis Nesti (Gassies, 1875; Dulignon-Desgranges, 1877; Welsch, 1911, 1917). In 1939, Fabre quotes in his synthesis Depéret and Mayet who attributed these remains to Mammuthus meridionalis var. cromerensis, a taxon contemporary to the Forest-Bed of Cromer (Middle Pleistocene, now referred to as M. trongontherii, Lister \& Stuart, 2010). Finally, Dubreuilh (1971) reports that the determination of the remains was reviewed by Prat and Aguirre, who reassigned them to the species Palaeoloxodon antiquus, Falconer and Cautley, 1847. The stratigraphic position of the mandible is well described: it was found within the Argiles du Gurp Formation, either in the green clay (Dulignon-Desgranges, 1877; Welsch, 1917), or in the overlying peat layer (Fabre, 1939).

In 1971, Dubreuilh found new remains of $P$. antiquus in the pebble level at the base of the Argiles du Gurp Formation. Other remains were also discovered in 1994 within a clay level in the area of La Balise. The disposition of the bone elements, in quasi-anatomical connection, testifies that the elephant was coeval with the marsh sediments (Beauval et al., 1998; Tastet, 1999). The species $P$. antiquus has been confirmed by a biometric study (Beauval et al., 1998). The remains were found with a mandible fragment of Dicerorhinus mercki, a species which shares the same biotope as the elephant, i.e. open forests and shrub-land.

The discovery in 2000 of a fragmentary mandible with two molars in the Argiles du Gurp Formation and of another isolated molar (ex situ) provided a new chronological indication. The remains belong to an ontogenetically older $P$. antiquus than the previous one. According to Michel (2002), these remains belonged to an antique elephant which may have lived "during the Eemian rather than during the Holsteinian” based on dental features. Recently, remains have been found again in the Argiles du Gurp in 2014 and 2016. They are composed respectively of a higher molar and a tusk fragment belonging to a $P$. antiquus (Beauval et al., 2019).

\section{4 - CHRONOLOGY}

The chronological interpretation is based upon different methods and approaches. According to the pollen analysis, the Argiles du Gurp and the Lignite sampled in five locations between La Balise and Anse du Gurp accumulated during an interglacial. After excluding the possibility of a deposition during the Cromerian (MIS 21-13) O’Brien and Jones (2003) favoured the final phase of the Holsteinian interglacial (MIS 11c) from a comparison with the data provided by other French lakes (Reille et al., 2000; de Beaulieu et al., 2001). The Eemien (MIS 5e) is excluded because of the presence of Azolla filiculoides and the differences with the pollen records in other French regions (Grande Pile : de Beaulieu \& Reille 1992; Les Echets : de Beaulieu \& Reille, 1984; Velay : de Beaulieu et al., 2001). However, the authors do not exclude the Landos interglacial (MIS 9e) or the Jagonas interstadial (MIS 11a).
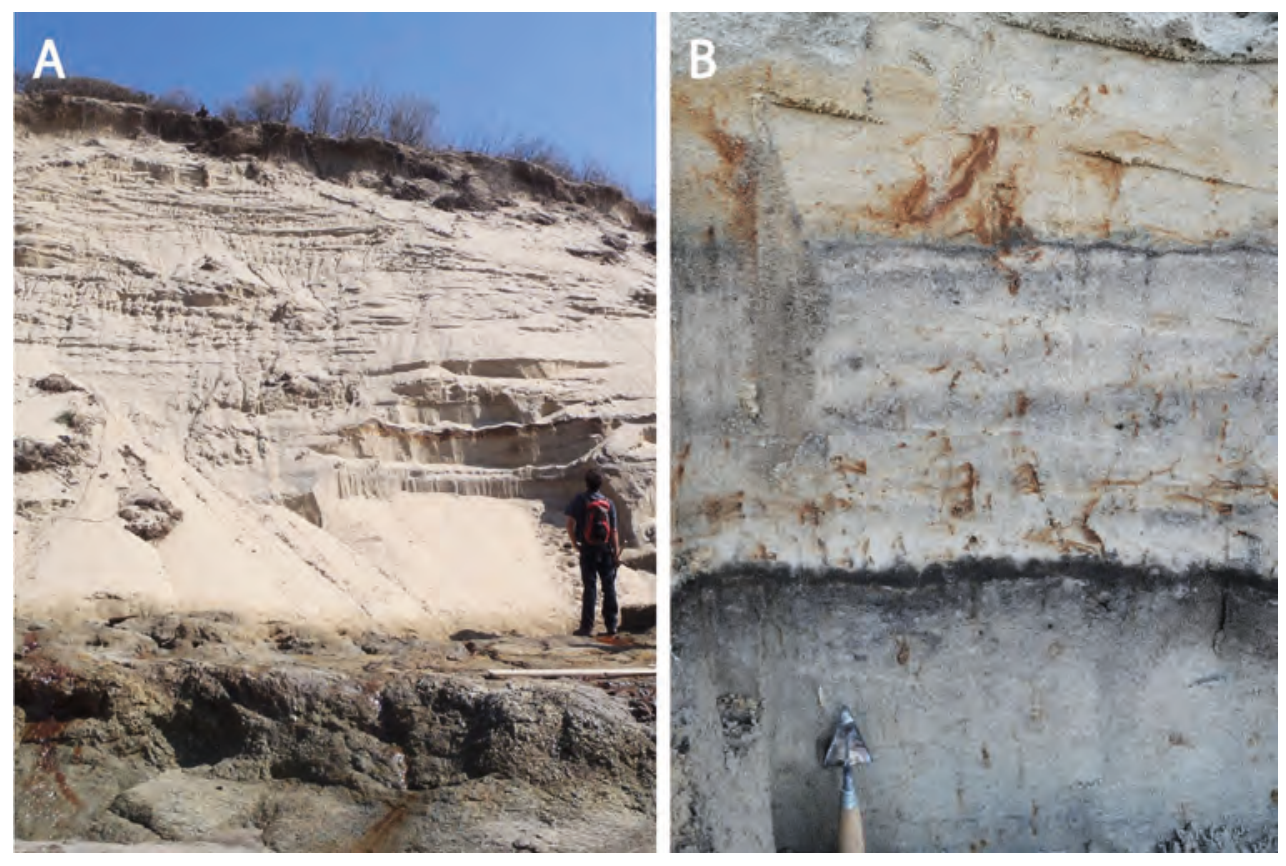

Fig. 11: Holocene dune.

A / Close up view of horizontal bioturbated sand beds with intercalated humic horizons in the lower part of the dune, L'Amélie; B/ Section of the Holocene dune overlaying the Argile du Gurp, L'Amélie; the cross beds have a strong dip perpendicular to the visible section (avalanche face of the dune).

Fig. 11 : Dune holocène. A/ Vue détaillée des sables bioturbés à litage horizontal et horizons humifères intercalés dans la partie inférieure de la dune, l'Amélie ; B/Coupe des dunes holocènes recouvrant les Argiles du Gurp, l'Amélie; les lits entrecroisés ont un fort pendage perpendiculairement à la coupe visible (face d'avalanche de la dune). 
The lower member of the Sables du Gurp Formation at Pointe de la Négade has been the subject of new IR-RF and ESR dating (Kreutzer et al., 2018) (Table 1). The samples yielded ages of $323 \pm 44 \mathrm{ka}$ (IR-RF, BDX16649), $220 \pm 28$ ka (ESR, BDX16649), $330 \pm 39$ ka (IR-RF, BDX16650) and $390 \pm 46 \mathrm{ka}$ (ESR, BDX16650) (Kreutzer et al., 2018). Assuming a similar bleaching behaviour and that two out of three ESR (Ti-H centres) are slightly older than the corresponding IR-RF ages, the ESR ages for sample BDX166490 appears to be an outlier. Excluding BDX16649-ESR, the ages indicate an interval between the end of MIS 12 and MIS 8 (Lisiecki \& Raymo, 2005; Railsback et al., 2015). The mean age (IR-RF, ESR) of $348 \pm 37 \mathrm{ka}$ and the periglacial depositional environment argue for a correlation to MIS 10 , which would be in agreement with the pollen-based estimate for the underlying Lignite (MIS 11).

The upper member of the Sables du Gurp Formation has been previously dated using ESR of quartz (Al centre) in 2014 (Sitzia, 2014; Sitzia et al., 2015). Following the basic principle of the MC approach these ESR ages should in first instance be considered as maximum possible ages in the absence of associated Ti-centre ESR ages (see Duval et al., 2017). The ESR ages obtained by these authors are highly consistent, $217 \pm 17$ ka (Gurp_2) and $222 \pm 31$ ka (Gurp_1), and suggest a deposition during MIS 8 or MIS 7. Nevertheless, the syngenetic frost fissures argue for a periglacial sedimentary context, supporting a MIS 8 age. The new independent age control is found to be consistent with the ESR-Al centre chronology and indicates that the $\mathrm{Al}$ signal has most likely been fully reset during sediment transport: the IR-RF age $220 \pm 28$ ka (BDX16647) obtained for the sands from the base of the filling of a small valley at L'Amélie is indeed similar and corresponds to MIS 8 as well.

The sample collected at the top of the basal green clays at L'Amélie displays an age of $289 \pm 34$ ka (IR-RF, BDX16648), i.e. MIS 9 - MIS 8. This age is younger than expected for the Argiles du Gurp Formation and cannot fit with MIS 11. Three possibilities can be envisaged to explain such an age: (1) secondary uranium enrichment took place in the form of ions adsorbed on clay or of oxides associated with the ferruginous cement ("Sables aliotisés”, Tastet, 1999) (Salminen et al., 2005) and induced significant uncertainty (here overestimation) in dose rate evaluation and an underestimation of the true burial age, (2) the corresponding equivalent dose (1064.1 $\pm 41 \mathrm{~Gy})$ of the IR-RF signal lays in a dose region previously considered as the upper limit for IR-RF dating (e.g., Erfurt \& Krbetschek, 2003), which would also likely underestimate the true burial dose, (3) the dated green clays do not belong to the Argile du Gurp Formation outcropping farther south (La Balise, Pointe de la Négade and Anse du Gurp) but correspond to MIS 9 estuarine deposits incised in older units. Because of similar depositional contexts and lithofacies and almost similar altitude (top of green clays is $+3.4 \mathrm{~m}$ a.s.l. at Pointe de la Négade versus $+2.2 \mathrm{~m}$ a.s.l. at L’Amélie), these clays were mistakenly attributed to a single geological formation. Since the lower member of the Sables du Gurp Formation is missing at L’Amélie, the latter hypothesis is favoured here.

Two OSL dates on quartz were also obtained for the Grès de l'Amélie, which fill in small valleys incised in

Table 1: Luminescence and ESR dating results (from Kreutzer et al., 2018).

Tableau 1 : Résultats des datations par Luminescence et ESR (d'après Kreutzer et al., 2018).

\begin{tabular}{|c|c|c|c|c|c|c|c|}
\hline Sample & $\mathbf{M}^{(\mathbf{1})}$ & Method & $\mathbf{N}^{(2)}$ & $\begin{array}{c}\text { Water }^{(3)} \\
{[\%]}\end{array}$ & $\begin{array}{c}\dot{\boldsymbol{D}}_{E n \boldsymbol{v}}{ }^{(4)} \\
{\left[\mathrm{Gy} \mathrm{ka}^{-1}\right]}\end{array}$ & $\begin{array}{c}\boldsymbol{D}_{\mathrm{E}} \\
{[\mathrm{Gy}]}\end{array}$ & $\begin{array}{c}\text { Age }^{(5)} \\
{[\mathrm{ka}]}\end{array}$ \\
\hline \multirow{2}{*}{ BDX16646 } & $\mathrm{Q}$ & OSL & $22 / 24$ & $21 \pm 9$ & $1.7 \pm 0.1$ & $42.0 \pm 5.7$ & $26 \pm 4$ \\
\hline & FS & IR-RF & $18 / 18$ & & $2.3 \pm 0.2$ & $91.7 \pm 7.2$ & $40 \pm 6$ \\
\hline \multirow[t]{2}{*}{ BDX16647 } & Q & OSL & 3 & $33 \pm 8$ & $1.3 \pm 0.1$ & $>238$ & $>179$ \\
\hline & FS & IR-RF & $10 / 20$ & & $2.0 \pm 0.2$ & $428.0 \pm 20.6$ & $220 \pm 28$ \\
\hline \multirow[t]{2}{*}{ BDX16648 } & $\mathrm{Q}$ & OSL & 3 & $34 \pm 7$ & $2.8 \pm 0.1$ & $>300$ & $>105$ \\
\hline & FS & IR-RF & $9 / 10$ & & $3.7 \pm 0.4$ & $1064.1 \pm 41$ & $289 \pm 34$ \\
\hline \multirow[t]{3}{*}{ BDX16649 } & $\mathrm{Q}$ & OSL & 3 & $7 \pm 3$ & $1.3 \pm 0.1$ & $>300$ & $>231$ \\
\hline & FS & IR-RF & $9 / 14$ & & $1.9 \pm 0.2$ & $618.2 \pm 38.7$ & $323 \pm 44$ \\
\hline & $\mathrm{Q}$ & ESR (Ti-H) & NA & & $1.3 \pm 0.1$ & $289 \pm 32$ & $219 \pm 27$ \\
\hline \multirow[t]{3}{*}{ BDX16650 } & $\mathrm{Q}$ & OSL & 3 & $7 \pm 3$ & $1.5 \pm 0.1$ & $206.2 \pm 73.3$ & $>136$ \\
\hline & FS & IR-RF & $11 / 16$ & & $2.1 \pm 0.2$ & $701.7 \pm 32.5$ & $330 \pm 39$ \\
\hline & $\mathrm{Q}$ & ESR (Ti-H) & NA & & $1.5 \pm 0.1$ & $596 \pm 65$ & $390 \pm 46$ \\
\hline \multirow[t]{3}{*}{ BDX16651 } & $\mathrm{Q}$ & OSL & $17 / 19$ & $21 \pm 9$ & $1.9 \pm 0.1$ & $47.7 \pm 8.9$ & $26 \pm 5$ \\
\hline & FS & IR-RF & $21 / 21$ & & $2.6 \pm 0.2$ & $96.2 \pm 8.0$ & $37 \pm 5$ \\
\hline & $\mathrm{Q}$ & ESR (Ti-H) & NA & & $2.0 \pm 0.2$ & $90 \pm 23$ & $45 \pm 12$ \\
\hline
\end{tabular}

(1) Mineral: Q = Quartz, FS = K-feldspar

(2) Number of measured aliquots (NA = not applicable)

(3) Water content used for the age calculation. The value was obtained from simulations using grain size information.

(4) The environmental dose rate includes cosmic and water corrected alpha-, beta- and gamma dose rates. For the ESR age results, an assumed internal dose rate of 0.005 Gy ka-1 was considered.

(5) For the age calculation numbers with a higher precision than those displayed here were used, i.e. the ratio of $\mathrm{D}_{\mathrm{E}} / \dot{D}_{\text {Env }}$ may differ due to round-off errors. 
the Sables du Gurp Formation. The ages of $26 \pm 5 \mathrm{ka}$ (BDX16651) and $26 \pm 4$ ka (BDX16646) (Kreutzer et al., 2018) are highly consistent and are contemporaneous with the Last Glacial Maximum. By contrast, IR-RF and ESR ages are older than the OSL ages (but indistinguishable within 2-sigma) and are likely to reflect the poor bleaching behaviour of the IR-RF and the ESR signal respectively. Against this background, IR-RF and ESR (Ti-H) would require a conservative interpretation as maximum age.

In summary, the luminescence and ESR dating results raise serious doubt about the validity of the radiocarbon ages obtained on the Lignite previously published by Dubreuilh (1971) and Tastet (1999), all close to 30 ka uncalibrated (29.8 \pm 1.7 ka BP, $33.2 \pm 1.7$ ka BP, $36.45 \pm 2.04 \mathrm{ka} \mathrm{BP})$. Following Tastet (1999), who already considered these ages to be "outside the limits of the ${ }^{14} \mathrm{C}$ method" and proposed an "age greater than 50,000 years BP, without further details”, we believe that these ages must be rejected, finite value being most likely due to the presence of recent illuviated organic matter and incomplete elimination by sample processing. Additional ${ }^{14} \mathrm{C}$ dates (Eynaud et al., 2016) on wood remains from the Lignite also gave inconsistent ${ }^{14} \mathrm{C}$ ages (34000 $\pm 1200 \mathrm{BP}$ and $48000 \pm 2900 \mathrm{BP}$ ).

The age model retained here for the Pleistocene sequence places the Argiles du Gurp and the Lignite outcropping from La Balise to Anse du Gurp within the MIS 11 interglacial and the Sables du Gurp lower member in the MIS 10 glacial. These sands were truncated during the following interglacial (MIS 9) and new estuarine units (green clay, organic clay) were deposited at L’Amélie. The whole sequence was then covered by the Sables du Gurp upper member in the course of the next glacial, MIS 8. An important hiatus separates these sands from the Grès de l'Amélie, which were deposited during the Weichselian (MIS 2) in small valleys eroding the Sables du Gurp. Late Holocene dunes buried the Pleistocene deposits all along the coast.

\section{5 - DISCUSSION}

\section{1 - ORIGIN OF THE SABLES DU GURPFORMATION}

Many arguments lead to the hypothesis of an aeolian deposition of the sands rather than a fluvial origin, as previously proposed. These arguments, already developed in part by Sitzia (2014) and Sitzia et al. (2015), include the sedimentary significance of the lithofacies, the geometry of the deposits, and their relationship with the alluvial terraces of the Garonne River. They are as follows:

(1) The dominantly sandy grain-size of the deposits, the horizontal stratification and inverse grading of some laminae are typical of the coversands (sandsheets, Kocurek \& Nielson, 1986) observed elsewhere in the region. These coversands, which formed during glacial periods of the Middle and Upper Pleistocene, are associated with low-amplitude dune ridges lacking avalanche faces. The inverse grading reflects the migration of wind ripples (Kocurek \& Dott, 1981), and is unknown in fluvial environments. Wavy, crinkly lamination is interpreted as adhesion features formed by saltation of sand grains on moist ground (Kocurek \& Fielder, 1982; Kocureck \& Nielson, 1986). Gleyed silty beds, with a grain-size of loess or sandy loess (Sitzia, 2014), have been described by other authors in the coversands of northern Europe (Ruegg, 1983; Schwan, 1986, 1988; Kasse, 1997) as well as in southwest France (Sitzia et al., 2015). They result from the capture by wet ground in interdune areas of fine particles transported in suspension, especially during periods when the sand transport is limited by the development of vegetation. These levels are frequently deformed by frost action because of their contrasting frost-susceptibility in comparison with the sand beds. As in many sections of regional coversands, small scattered gravel clasts are locally present in the sand. They testify to the transport of gravel by storms from outcrops of coarse-grained material. Ventifacts were already reported by Dubreuilh and Marionnaud (1973). In total, the observed lithofacies indicate an aeolian deposition in a wet environment ("wet coversand") as defined by Kocurek and Havholm (1993). The decrease in the frequency and thickness of silt levels toward the top of the sequence is interpreted as a trend towards a drier aeolian context due to deepening of the groundwater table. The lack of cross-bedding, current ripples and clay levels makes it possible to exclude fluvial dynamics as the main mode of deposition.

(2) The small syngenetic frost fissures indicate that the upper member of the Sables du Gurp Formation was deposited in a periglacial context, presumably during MIS 8 . The presence of sandy fluvial deposits in the study area during the Middle Pleistocene appears inconsistent with the evolution of the Garonne River such as it can be reconstructed from the terrace system. At that time, the river bed was located much farther to the northeast and at lower altitude (i.e. below the current sea level) due to sea-level lowering during the glacial period. This lowering was approximately similar in MIS 10 to that reached during the last glacial period, i.e. close to $-130 \mathrm{~m}$ (Waelbroeck et al., 2002; Bintanja et al., 2005). It was a little weaker during MIS 8 (ca. -100 m). Therefore, the presence of relatively coarse (sandy) fluvial deposits in the study area appears difficult to explain.

As a conclusion, the sands correspond to aeolian sandsheet deposits in a wet context with deep seasonal frost and reduced vegetation cover. The gradual transition between the basal peat (Lignite) and the sands suggests that the latter gradually filled the coastal marsh where the Argiles du Gurp formed, following sea-level lowering and the installation of a periglacial environment. In some sections, clayey sands and gravel are interlayered within sands. This lithofacies is interpreted as colluvium that filled interdune depressions (see Langford, 1989) or valleys incised in the aeolian deposits. The difficulty of following the levels over distances of several tens of metres did not allow detailed understanding of the stratigraphic relationships between the aeolian and the colluvium-dominated deposits. 


\section{2 - AGE OF THE ELEPHANT REMAINS}

The Pleistocene coastal deposits have yielded several individuals attributed to Palaeoloxodon antiquus. These findings are of great interest because of the scarcity of the remains of this taxon in France (Crochet et al., 1996). The stratigraphic data collected indicate that all the remains, for which precise location is available, originate from the same formation: the Argiles du Gurp and the Lignite dated to MIS 11. P. antiquus is known in Europe from the early Middle Pleistocene to the Upper Pleistocene. It was adapted to warm humid forests and, consequently, was especially abundant during the interglacials (Guérin \& Patou-Mathis, 1996). P. antiquus was common during the Holsteinian (MIS 11) and the Eemian (MIS 5e). It was present throughout Europe, including in the north (Pushkina, 2007). At the end of the Eemian, when the climate became colder and the vegetation scarcer, it migrated to refuge areas (Iberian Peninsula, Italy) where it lasted until ca. 50-40 ka, or even up to 34-33 ka (Stuart, 2005; Mol et al., 2007).

The individuals discovered in the Argiles du Gurp show evolved dental features (high laminar frequency, high hypsodontia, low enamel thickness) according to Aguirre et al. (1973). For this reason, Michel (2002) assigned the remains to the Eemian rather than to the Holsteinian. However, although these palaeontological criteria make it possible to distinguish the first African elephants from the last individuals before they left Africa, they do not allow distinction between late Middle Pleistocene and Upper Pleistocene individuals. Indeed, the evolutionary trend observed in Africa does not seem to persist beyond 450 ka (Palombo \& Ferretti, 2005), and it seems not to be valid for European fossil elephants (Lister, 2015). Differentiation between MIS 11 and MIS 5 remains is thus impossible. Rivals et al. (2012) hypothesized that the last fossil elephants would have had a more grazing diet, but this result remain preliminary and does not thus far allow a chronology to be based on this criterion.

As a conclusion, all available palaeontological material (except for a fragmentary mandible of $D$. mercki) yielded by the Argiles du Gurp Formation is assigned to the species Palaeoloxodon antiquus and was correlated to the temperate MIS 11 interglacial based on independent numerical age control.

\section{3 - EVOLUTION OF THE DEPOSITIONAL ENVIRONMENTS IN THE MÉDOC PENINSULA FROM THE MIDDLE PLEISTOCENE TO THE HOLOCENE}

\subsection{1 - The estuarine system (Lower to Middle Pleistocene)}

The new field observations coupled with the data from the literature show that the Négade Formation (MIS 79-63, 49-37 or 31-22) and the lower part of the Argiles du Gurp (MIS 11) were deposited in an estuarine environment connected to a high sea level. These two formations belong to distinct interglacials separated by a sedimentary hiatus that covers several hundreds of thousands of years or even nearly a million years. This hiatus corresponds to a surface of marine abrasion, presumably associated with the MIS 11 sea-level maximum (6 to 13 m a.s.l., Spratt \& Lisieki, 2016). The borehole data suggest that the Argiles du Gurp Formation and the overlying aeolian sands are unconformably lying over the Fvb alluvium of the Garonne River. The surface of marine abrasion continues eastward (i.e. landward) to an old coastal cliff buried by aeolian sands. The top of the Argiles du Gurp shows a change in the sedimentary dynamics with gradual shift from a tidal environment to a freshwater pond (O’Brien \& Jones, 2003). According to pollen analysis, this change is associated with a modification of the regional vegetation. Decreased marine influence indicates isolation of the pond either because of its progressive filling or of sea-level lowering. At the end of the MIS 11 interglacial, the development of a reed bed dominated by sedges (Lignite) testifies to the complete filling of the freshwater pond.

Luminescence dating of estuarine clays at L'Amélie strongly suggests that they were deposited during the MIS 9 interglacial and, thus, correspond to a sedimentary unit distinct from the Argiles du Gurp Formation and so far unrecognised because of strong similarities in lithofacies. This unit (“Argiles de l'Amélie”), which lies unconformably over previous deposits, indicates progressive northward shifting of the Garonne estuary during the Pleistocene. It has to be noted that MIS 11 and 9 correspond to the highest sea levels in the last $800 \mathrm{ka}$ together with MIS 5e (Spratt \& Lisieki, 2016) and are equally well represented in the Pleistocene record along the European Atlantic coast (Roe et al., 2009; Barlow et al., 2017). In the Médoc area, these levels (although probably not corresponding to the interglacial thermal maximum) are roughly at the same altitude as the modern shoreline, suggesting that the regional uplift since the Middle Pleistocene (at least along the Atlantic side of Médoc) was limited unlike in many parts of western Europe (Bridgland, 2000; Bridgland \& Westaway, 2008). Some 120 km farther south, Klingebiel and Legigan (1992) showed that the basin centre is currently undergoing subsidence by about $0.5 \mathrm{~mm} \mathrm{yr}^{-1}$.

\subsection{2 - The aeolian system (Middle to Upper Pleistocene)}

At the beginning of MIS 10, in connection with the development of periglacial conditions and the ensuing reduction of vegetation cover, the filling of the coastal ponds ends with the deposition of aeolian sands (lower member of the Sables du Gurp Formation). The lithofacies indicate that the groundwater table was close to the surface, at least seasonally, and periodically allowed the capture of wind-blown dust in wet depressions.

The new OSL, IR-RF and ESR dates unambiguously show that the emplacement of the aeolian deposits preserved along the coast occurred during different isotopic stages, mainly during the glacial periods (with the exception of the Late Holocene dunes). The ages obtained on the Sables du Gurp Formation indicates that it is not homogeneous, but was most likely formed during 
two successive glacials, MIS 10 and 8.

The hiatus between the two units is marked by an unconformity overlain by ventifacts, or locally by a sandy clay colluvium. This unconformity reflects incision of deposits by small valleys and gullies. The valleys which cut the Sables du Gurp upper member, filled with colluvium dated to MIS 2, were identified previously by many authors (Fabre, 1939; Dubreuilh, 1971; Tastet, 1999) and were correlated by Tastet to the hydrographic system which drains the Médoc peninsula towards the Garonne.

At the regional scale, sandsheets similar to the Sables du Gurp have been described in many sections in the Plateau Girondin, south of the Médoc region (Sitzia, 2014, Sitzia et al., 2015). Numerical ages show that they are Middle to Upper Pleistocene and range from MIS 10 to MIS 3. The coversands were deposited either in moist (adhesion ripples, silty layers, especially during MIS 3) or dry context (sands with subhorizontal bedding). The lack of recent ages (i.e. MIS 2) on the Plateau Girondin was explained by Sitzia et al. (2015) as being related to the remoteness of the coastline during the Last Glacial Maximum (LGM). The shoreline at -120 m was located more than $160 \mathrm{~km}$ west of the Pointe du Médoc during the LGM. The coversands which progressed inland from the (now submerged) coast did not reach the currently subaerial part of Médoc. Conversely, in the southern part of the basin, where the coastline at -120 m was only about $40 \mathrm{~km}$ from the current shore, thick aeolian formations accumulated during the LGM. A similar pattern seems also to have existed during the penultimate glacial, MIS 6. These coversands, increasing in thickness toward the ocean, constitute the Sables des Landes Formation sensu lato. The Sables du Gurp Formation must, therefore, be considered as a local equivalent to the Sables des Landes.

\section{6 - CONCLUSION}

Detailed lithostratigraphy and numerical dating (ESR, OSL, IR-RF) of new cross-sections make it possible to further constrain the chronology of the Pleistocene deposits outcropping along the coast of the Médoc region, southwest France. The sequence, which unconformably overlays Lower Pleistocene estuarine deposits (Négade Formation), was mainly formed during the Middle Pleistocene. It comprises basal marsh deposits, initially influenced by the tide, then deposited in a freshwater context (green clays and peat of the Argiles du Gurp Formation) during a high sea level corresponding to the Holsteinian interglacial (MIS 11). The proposed depositional environment is that of a pond in an estuarine environment. IR-RF dating of green clay at L'Amélie suggests that an estuarine MIS 9 unit is also preserved in the northernmost part of the study area. The coast was covered during the following glacials by aeolian sandsheets (Sables du Gurp Formation), which represent a local equivalent of the Sables des Landes already described more inland in the Médoc peninsula.
The ages obtained on the Sables du Gurp show that these were mainly deposited during MIS 10 and 8 . Deposits corresponding to more recent glacials are virtually non-existent. Only thin layers of aeolian sands and colluvium in small valleys incised in the Sables du Gurp have been dated to the Weichselian (MIS 2).

The chronostratigraphical revision also made it possible to attribute the abundant remains of Palaeoloxodon antiquus discovered in the area to MIS 11. Together, these remains constitute an important collection for the knowledge of this species, which is little represented in the faunal assemblages of the French Pleistocene.

\section{ACKNOWLEDGMENTS}

The LITAQ project was financed by the Agence Nationale de la Recherche under the Programme Investissement d'Avenir (reference ANR-10IDEX-03-02). We thank F. Verdin and F. Eynaud, in charge of the project, for giving us the opportunity to study the Pleistocene formations of the Médoc region, and the other participants, Frédéric Bertrand, Gilles Arnaud-Fassetta, Anne Colin, Antoine Kremer, Clément Lambert, Serge Suanez, Clément Coutelier, Stéphane Costa and Nathalie Prévôt. We also thank J.P. Tastet, who introduced us to the site during a previous field campaign, and A. Queffelec for carrying out grain size analyses. $\mathrm{S}$. Kreutzer received financial support by the LaScArBx. LaScArBx is a research programme supported by the ANR (ANR-10-LABX-52). The ESR dating analyses have been funded by the Australian Research Council Future Fellowship grant FT150100215. D. Bridgland and an anonymous reviewer are acknowledged for their remarks, which contributed to improve the original manuscript.

\section{REFERENCES}

AGUIRRE E., LHENAFF R. \& ZAZO C., 1973 - Nuevos fossiles de elefantes en Andalucia. Estudio geologicos, 29, 295-306.

ANDRIEUX E., BERTRAN P. \& SAITO K., 2016 - Spatial analysis of the French Pleistocene permafrost by a GIS database. Permafrost and Periglacial Processes, 27 (1), 17-30.

BARLOW N.L.M., LONG A.J., GEHRELS W.R., SAHER M.H., SCAIFE R.G., DAVIES H.J., PENKMAN K.E.H., BRIDGLAND D.R., SPARKES A., SMART C.W. \& TAYLOR S., 2017 - Relative sea-level variability during the late Middle Pleistocene: New evidence from eastern England. Quaternary Science Reviews, 173, 20-39.

BEAUVAL C., MICHEL P. \& TASTET, J.P., 1998 - L'éléphant antique de Soulac (Gironde, France). Quaternaire, 9 (2), 91-100.

BEAUVAL C., MICHEL P., BOSQ M., BERTRAN P., LACRAMPECUYAUBËRE F. \& PASTY S., 2019 - A new straight-tusked elephant tooth from Soulac-sur-Mer (Gironde, France). Review of elephant discoveries in the Northern Médoc. Quaternaire, 30 (1), 21-30

BERTRAN P., ALLENET G., GÉ T., NAUGHTON F., POIRIER P. \& SANCHEZ-GOÑI M.F., 2009 - Coversand and Pleistocene palaeosols in the Landes region, southwestern France. Journal of Quaternary Science, 26 (3), 259-269.

BERTRAN P., BATEMAN M.D., HERNANDEZ M., MERCIER N., MILLET D., SITZIA L. \& TASTET J.P., 2011 - Inland aeolian deposits of south-west France: facies, stratigraphy and chronology. Journal of Quaternary Science, 26 (4), 374-388. 
BERTRAN P., ANDRIEUX E., ANTOINE P., DESCHODT L., FONT M. \& SICILIA D., 2017 - Pleistocene involutions and patterned ground in France: examples and analysis using a GIS database. Permafrost and Periglacial Processes, 28, 710-725, DOI 10.1002/ppp.1957.

BINTANJA R., VAN DE WAL R.S.W. \& OERLEMANS J., 1995 - Modelled atmospheric temperatures and global sea levels over the past million years. Nature, 437 (7055), 125-128.

BRIDGLAND D.R., 2000 - River terrace systems in north-west Europe: an archive of environmental change, uplift and early human occupation. Quaternary Science Reviews, 19, 1293-1303.

BRIDGLAND D.R. \& WESTAWAY R., 2008 - Climatically controlled river terrace staircases: A worldwide Quaternary phenomenon. Geomorphology, 98, 285-315.

CLARKE M.L., RENDELL H.M. \& PYE K., 1999 - Evidence for the timing of dune development on the Aquitaine Coast, southwest France. Zeitschrift für geomorphologie, supplement band, 116, 147-163.

CLARKE M., RENDELL H., TASTET J.P., CLAVÉ B. \& MASSÉ L. 2002 - Late-Holocene sand invasion and North Atlantic storminess along the Aquitaine Coast, southwest France. The Holocene, 12 (2), 231-238.

CLAVÉ B., 2001 - Évolution des paléo-environnements côtiers à l'Holocène: exemple de l'Aquitaine septentrionale. Thèse de doctorat, université de Bordeaux 1, Bordeaux, 316 p.

COQUILLAS D., DIOT M.F, CLAVÉ B \& TASTET J.P, 2006 - L’homme dans les paysages côtiers du Nord Médoc (Gironde), entre Néolithique et âge du Fer. Actes des 6èmes Rencontres de Préhistoire Récente 2004, Périgueux, 55-70.

COURRÈGES M., 1997 - Le crypto-karst de la péninsule du Médoc. Crypto-altération, dissolution, karst sous-marin et évolution quaternaire. Quaternaire, 8 (2), 289-304.

CROCHET J.Y., ASTRUC J.G., HUGONIE L., MARANDAT B., SIGÉ B. \& SUDRE J., 1996 - Un éléphant antique, Palaeoloxodon antiquus (Falconer et Cautley, 1847) sur le causse de Gramat (Lot, France) Bulletin de la Société d'Histoire Naturelle de Toulouse, 132, 71-75.

DE BEAULIEU J.L. \& REILLE M., 1984 - A long upper Pleistocene pollen record from Les Echets, near Lyon, France. Boreas, 13 (2), 111-132.

DE BEAULIEU J.L. \& REILLE M., 1992 - The last climatic cycle at La Grand Pile (Vosges, France) a new pollen profile. Quaternary Science Reviews, 11 (4), 431-438.

DE BEAULIEU J.L., ANDRIEU-PONEL V., REILLE M., GRÛGER E, TZEDAKIS C. \& SVOVODOVA H., 2001 - An attempt at correlation between the Velay pollen sequence and the Middle Pleistocene stratigraphy from central Europe. Quaternary Science Reviews, 20 (16), 1593-1602.

DIOT M.F., 1999 - Le Pléistocène de la façade atlantique du NordMédoc (France) : synthèse sur la palynologie des « Argiles du Gurp » s.l. et comparaison avec les données de l’Aquitaine. Quaternaire, 10 (2-3), 213-225

DIOT M.F. \& TASTET J.-P., 1995 - Paléo-environnements holocènes et limites chronoclimatiques enregistrés dans un marais estuarien de la Gironde (France). Quaternaire, 6 (2), 63-75.

DUBREUILH J., 1971 - Étude géologique des formations quaternaires du Bas-Médoc. Essai de corrélations stratigraphiques. Mémoire de DEA, université de Bordeaux 1, Bordeaux, 158 p.

DUBREUILH J., L'HOMER A., MARIONNAUD J.M. \& THIBAULT C., 1971 - Observations nouvelles sur le Quaternaire de la région du Gurp (Gironde). Comptes-Rendus Sommaires des Séances de la Société Géologique de France, 1, 28-29.

DUBREUILH J. \& MARIONNAUD J.M., 1973 - Carte géologique de la France à 1/50 000 ( $n^{\circ}$ 729-730) St-Vivien de Médoc - Soulacsur-Mer. Notice explicative. Bureau de Recherches Géologiques et Minières, Orléans, $47 \mathrm{p}$

DUBREUILH J., CAPDEVILLE J.P., FARJANEL G., KARNAY G., PLATEL J.P. \& SIMON-COINÇON, 1995 - Dynamique d'un comblement continental néogène et quaternaire : l'exemple du bassin d'Aquitaine. Géologie de la France, 4, 3-26.

DULIGNON-DESGRANGES A., 1877 - Excursion sur le littoral de Gascogne. Actes de la Société Linnéenne de Bordeaux, 31, 41-60.

DURCAN J.A., KING G.E. \& DULLER G.A.T., 2015 - DRAC: Dose Rate and Age Calculator for trapped charge dating. Quaternary Geochronology, 28, 54-61.

DUVAL M., ARNOLD L.J., GUILARTE V., DEMURO M, SANTONJA M. \& PÉREZ-GONZÁLEZ A., 2017 - Electro Spin Resonance dating of optically bleached quartz grains from the Middle Palaeolithic site of Cuesta de la Bajada (Spain) using the multiple centres approach. Quaternary Geochronology, 37, 82-96.
ELHAÏ H. \& PRENANT A., 1963 - Présence et extension d'un niveau marin littoral interglaciaire sur la côte du Médoc. Bulletin de la société géologique de France, 7, 495-507.

ERFURT G. \& KRBETSCHEK M.R., 2003 - IRSAR - A singlealiquot regenerative-dose dating protocol applied to the infrared radiofluorescence (IR-RF) of coarse-grain K-feldspar. Ancient $T L$, 21, 35-42.

EYNAUDF., L.LONDEIX, M.BOSQ \& S.FAYE, 2016-Le contexte stratigraphique général - Lède du Gurp - (Grayan-et-l'Hôpital, Gironde). Rapport Final d'Opération, Fouille programmée du site de la Lède du Gurp, sous la direction de F. Verdin (CNRS, Ausonius), octobre 2014, programme financé par le Ministère de la Culture.

FABRE A., 1939 - Les terrains de revêtement du Médoc, Drouillard, Bordeaux, $334 \mathrm{p}$.

FRIEDMAN J.D., JOHANSSON C.E., OSKARSSON N., SVENSSON H., THORARINSSON S. \& WILLIAMS Jr R.S., 1971 - Observations on Icelandic polygon surfaces and palsa areas. Photo interpretation and field studies. Geografiska Annaler, Series A. Physical Geography, 53A, 115-145

FROIDEFOND J.M., FRAPPA, M., GAYET, J., DE RESSEGUIER, A. \& VIGNEAUX, M., 1984 - Réalisation d'une carte bathymétrique et reconnaissance géomorphologique et géologique des roches sous-marines de la côte du Médoc (Gironde). Bulletin de l'Institut de Géologie du Bassin Aquitain, 35, 5-21.

FROUIN M., HUOT S., KREUTZER S., LAHAYE C., LAMOTHE M., PHILIPPE A. \& MERCIER N., 2017 - An improved radiofluorescence single-aliquot regenerative dose protocol for K-feldspars. Quaternary Geochronology, 38, 13-24.

GASSIES J.B., 1875 - Découverte au Gurp d'une mâchoire fossile d'éléphant. Actes de la Société Linnéenne de Bordeaux, 30, 134.

GUÉRIN C. \& PATOU-MATHIS M., 1996 - Les grands mammifères plio-pléistocènes d'Europe. Dunod, Paris, 291 p.

GUÉRIN G. \& MERCIER N., 2011 - Determining gamma dose rates by field gamma spectroscopy in sedimentary media: Results of Monte Carlo simulations. Radiation Measurements, 46, 190-195.

GUILLORÉ P., 1980 - Méthode de fabrication mécanique et en série des lames minces. CNRS \& Institut National d'Agronomie ParisGrignon, $22 \mathrm{p}$

HASLAM S.M., SINKER C.A. \& WOLSELEY P.A., 1982 - British water plants. Field Studies, 4, 243-351.

ISO, 2009 - ISO 13320, Particle size analysis - Laser diffraction methods (https://www.iso.org/standard/44929.html).

JONES R.M., 2003 - Particle size analysis by laser diffraction: ISO 13320, standard operating procedures, and Mie theory. American Laboratory, 35 (1), 44-47.

KARNAY G., CORBIER P., BOURGINE B. \& SALTEL M., 2010 - Gestion des eaux souterraines en région Aquitaine. Reconnaissance des potentialités aquifères du Mio-PlioQuaternaire des Landes de Gascogne et du Médoc en relation avec les SAGE. Rapport final, BRGM/RP-57813-FR, BRGM, Orléans, $77 \mathrm{p}$

KASSE C., 1997 - Cold-Climate Aeolian Sand-Sheet Formation in North-Western Europe (c. 14-12.4 ka); a Response to Permafrost Degradation and Increased Aridity. Permafrost and Periglacial Processes, 8 (3), 295-311.

KLINGEBIEL A. \& LEGIGAN P., 1992 - Cadre géologique et structure du bassin de la Leyre. Bulletin de l'Institut de Géologie du Bassin d'Aquitaine, 51-52, 7-20.

KOCUREK C. \& DOTT JR. R.H, 1981 - Distinctions and uses of stratification types in the interpretation of eolian sands. Journal of Sedimentary Petrology, 51 (2), 579-595.

KOCUREK G. \& FIELDER G., 1982 - Adhesion structures. Journal of Sedimentary Research, 52 (4), 1229-1241.

KOCUREK G. \& NIELSON J., 1986 - Conditions favourable for the formation of warm-climate aeolian sand sheets. Sedimentology, 33 (6), 795-816.

KOCUREK G. \& HAVHOLM K.G., 1993 - Eolian sequence stratigraphy-a conceptual framework. In P. Weimer \& $\mathrm{H}$. Posamentier (eds.), Siliciclastic Sequence Stratigraphy. Tulsa, 16 393-409.

KREUTZER S., SCHMIDT C., FUCHS M.C., DIETZE M., FISCHER M. \& FUCHS M., 2012 - Introducing an R package for luminescence dating analysis. Ancient TL, 30 (1), 1-8.

KREUTZER S., DIETZE M., BUROW, C., FUCHS M.C., SCHMIDT C., FISCHER M. \& FRIEDRICH J., 2017- Luminescence: Comprehensive Luminescence Dating Data Analysis. R package version 0.7.4. https://CRAN.R-project.org/ package=Luminescence. 
KREUTZER S., DUVAL M., BARTZ M., BERTRAN P., BOSQ M., EYNAUD F., VERDIN F. \& MERCIER N., 2018 - Deciphering Costal Dynamics using IR-RF and ESR dating: a case study from Médoc, France. Quaternary Geochronology, 48, 108-120.

LANGFORD R.P., 1989 - Fluvial-aeolian interactions: Part I. Modern systems. Sedimentology, 36 (6), 1023-1035.

LEGIGAN P., 1979 - L'élaboration de la formation du Sable des Landes. Dépôt résiduel de l'environnement sédimentaire pliocènepléistocène centre aquitain. Mémoires de l'Institut de Géologie du bassin d'Aquitaine, Bordeaux, $451 \mathrm{p}$.

LISIECKI L.E. \& RAYMO M.E., 2005 - A Pliocene-Pleistocene stack of 57 globally distributed benthic $\delta^{18} \mathrm{O}$ records. Paleoceanography, 20 (1), 1-17.

LISTER A.M., 2015 - Dating the arrival of straight-tusked elephant (Palaeoloxodon spp.). Bulletin du Musée d'Anthropologie Préhistorique de Monaco, Eurasia, suppl. n 6, 13-18.

LISTER, A.M. \& STUART, A.J., 2010- The West Runton mammoth (Mammuthus trogontherii) and its evolutionary significance. Quaternary International, 228, 180-209.

MERCIER N. \& FALGUÈRES C., 2007 - Field gamma dose-rate measurement with a $\mathrm{NaI}(\mathrm{Tl})$ detector: re-evaluation of the 'threshold' technique. Ancient TL, 25, 1-4.

MICHEL P., 2002 - Nouvelles découvertes d'ossements d'Eléphant antique (Palaeoloxodon Antiquus) à Soulac (Gironde, France). Quaternaire, 13 (2), 105-110.

MOL D., DE VOS J. \& VAN DER PLICHT J., 2007 - The presence and extinction of Elephas antiquus Falconer and Cautley, 1847, in Europe. Quaternary International, 169-170, 149-153.

MURRAY, A.S. \& WINTLE, A.G., 2000 - Luminescence dating of quartz using an improved single-aliquot regenerative-dose protocol. Radiation Measurements, 32, 57-73.

MURTON J.B., 2013 - Permafrost and Periglacial Features. Ice Wedges and Ice-Wedge Casts. In Encyclopedia of Quaternary Science. Elsevier, Amsterdam, 436-451.

O'BRIEN C.E. \& JONES R.L., 2003 - Early and Middle Pleistocene vegetation history of the Medoc region, southwest France. Journal of Quaternary Science, 18 (6), 557-579.

PALOMBO M.R. \& FERETTI M.P., 2005 - The italian elephant fossil record : knowledge, problems and perpectives. Quaternary International, 126-128, 107-136.

PAQUEREAU M.M. \& SCHOELLER M., 1959- Quaternaire et Pliocène du Gurp (Gironde). Bulletin de la société géologique de France, 1 (1), 79-83.

PONTEE N., TASTET J.P. \& MASSÉ L., 1998 - Morphosedimentary evidence of Holocene coastal changes near the mouth of the Gironde and on the Medoc Peninsula, SW France. International Conference on Oceanography of the Bay of Biscay, 21 (2), 243-261.

PREUSSER, F., DEGERING, D., FUCHS, M., HILGERS, A., KADEREIT, A., KLASEN, N., KRBETSCHEK, M.R., RICHTER, D. \& SPENCER, J.Q.G., 2008 - Luminescence dating: basics, methods and applications. Eiszeitalter und Gegenwart (Quaternary Science Journal) 57, 95-149.

PUSHKINA D., 2007 - The Pleistocene easternmost distribution in Eurasia of the species associated with the Eemian Palaeoloxodon antiquus assemblage. Mammal Review, 37 (3), 224-245.

RAILSBACK L.B., GIBBARD P.L., HEAD M.J., VOARINTSOA N.R.G. \& TOUCANNE S., 2015 - An optimized scheme of lettered marine isotope substages for the last 1.0 million years, and the climatostratigraphic nature of isotope stages and substages. Quaternary Science Reviews, 11, 94-106.

REILLE M., DE BEAULIEU J.L., SVOBODOVA H., ANDRIEUPONEL V. \& GOEURY C., 2000 - Pollen analytical biostratigraphy of the last five climatic cycles from a long continental sequence from the Velay region (Massif Central, France). Journal of Quaternary Science, 15 (7), 665-685.

REINECK H.E. \& SINGH I.B., 1980 - Depositional Sedimentary Environments, with Reference to Terrigenous Clastics. Springer, Berlin, $570 \mathrm{p}$.

RIVALS F., SEMPREBON G. \& LISTER A., 2012 - An examination of dietary diversity patterns in Pleistocene proboscideans (Mammuthus, Palaeoloxodon, and Mammut) from Europe and North America as revealed by dental microwear. Quaternary International, 255, 188-195.

ROE H.M., COOPE G.R., DEVOY R.J.M., HARRISON C.J.O., PENKMAN K.E.H., PREECE R.C. \& SCHREVE D.C., 2009 - Differentiation of MIS 9 and MIS 11 in the continental record: vegetational, faunal, aminostratigraphic and sea-level evidence from coastal sites in Essex, UK. Quaternary Science Reviews, 28, 2342-2373.
ROMANOVSKIJ N.N., 1973 - Regularities in formation of frostfissures and development of frost-fissure polygons. Biuletyn Peryglacjalny, 23, 237-277.

RUEGG G.H.J., 1983 - Periglacial eolian evenly laminated sandy deposits in the Late Pleistocene of NW Europe, a facies unrecorded in modern sedimentological handbooks. In Developments in Sedimentology. Elsevier, Amsterdam, 38, 455-482.

SALMINEN R., BATISTA M.J., BIDOVEC M., DEMETRIADES A., DE VIVO B., DE VOS W., DURIS M., GILUCIS A., GREGORAUSKIENE V., HALAMIC J., HEITZMANN P., LIMA A., JORDAN G., KLAVER G., KLEIN P., LIS J., LOCUTURA J., MARSINA K., MAZREKU A., O'CONNOR P.J., OLSSON S.A., OTTESEN R.-T., PETERSELL V., PLANT J.A., REEDERS., SALPETEUR I., SANDSTROMH., SIEWERS U., STEENFELT A. \& TARVAINEN T., 2005 - Geochemical atlas of Europe. Part 1: Background Information, Methodology and Maps. Geological Survey of Finland, Espoo (http://www.gtk. fi/publ/foregsatlas)

SCHWAN J., 1986 - The origin of horizontal alternating bedding in weichselian aeolian sands in Northwestern Europe. Sedimentary Geology, 49 (1-2), 73-108.

SCHWAN J., 1988 - The structure and genesis of Weichselian to early hologene aeolian sand sheets in western Europe. Sedimentary Geology, 55 (3-4), 197-232.

SITZIA L., 2014 - Chronostratigraphie et distribution spatiale des dépôts éoliens quaternaires du Bassin Aquitain. Thèse de doctorat, université de Bordeaux 1, Bordeaux, 337 p.

SITZIA L., BERTRAN P., BAHAIN J.J., BATEMAN M.D., HERNANDEZ M., GARON H. DE LAFONTAINE G., MERCIER N., LEROYER C., QUEFFELEC A. \& VOINCHET P., 2015 - The Quaternary coversands of southwest France. Quaternary Science Reviews, 124, 84-105.

SPRATT R.M. \& LISIEKI L.E., 2016 - A Late Pleistocene sea level stack. Climate of the Past, 12, 1079-1092.

STUART A.J., 2005 - The extinction of woolly mammoth (Mammuthus primigenius) and straight-tusked elephant (Palaeoloxodon antiquus) in Europe. Quaternary International, 126-128, 171-177.

TASTET J.P., 1998 - Chronologie et cartographie d'un complexe dunaire côtier holocène, l'exemple aquitain du Nord-Médoc (France). Quaternaire, 9 (3), 157-167.

TASTET J.P., 1999 - Le Pléistocène de la façade atlantique du NordMédoc (France) : état des connaissances sur la lithologie et la chronostratigraphie des « Argiles du Gurp » s.l. Quaternaire, 10 (2), 199-212.

TASTET J.P. \& PONTEE N.I., 1998 - Morpho-chronology of coastal dunes in Médoc. A new interpretation of Holocene dunes in Southwestern France. Geomorphology, 25 (1-2), 93-109.

TASTET J.P. \& BECHELER P., 2012 - Les terrasses quaternaires du Médoc, l'exemple de l'AOC Margaux. Quaternaire continental d'Aquitaine : un point sur les travaux récents, Guidebook of the AFEQ-ASF, 153-160.

TOYODA S., VOINCHET P., FALGUÈRES C., DOLO J.M. \& LAURENT M., 2000 - Bleaching of ESR signals by the sunlight: a laboratory experiment for establishing the ESR dating of sediments. Applied Radiation and Isotopes, 52, 1357-1362.

TRAUTMANN T., KRBETSCHEK M.R., DIETRICHA. \& STOLZ W., 1999 - Feldspar radioluminescence: a new dating method and its physical background. Journal of Luminescence, 85, 45-58.

VANDENBERGHE J. 2013 - Cryoturbation structures, In S.A. Elias \& C.J. Mock, (eds.) Encyclopedia of Quaternary Science, Elsevier, Amsterdam, 430-435.

VIGNEAUX M., 1975 - Aquitaine occidentale. Masson, Paris, 223 p.

WAELBROECK C., LABEYRIE L., MICHEL E., DUPLESSY J.C., MCMANUS J.F., LAMBECK K., BALBON E. \& LABRACHERIE M., 2002 - Sea-level and deep water temperature changes derived from benthic foraminifera isotopic records. Quaternary Science Reviews, 21 (1), 295-305.

WELSCH J., 1911 - Feuille de La Rochelle au 320.000 . Notes géologiques sur les environs de Lesparre et de Blaye. Bulletin de la Carte Géologique de France, 21 (132), 441-454.

WELSCH J., 1917 - Les lignites du littoral et les forêts submergées de l’Ouest de la France. L'Anthropologie, 23, 201-233. 